


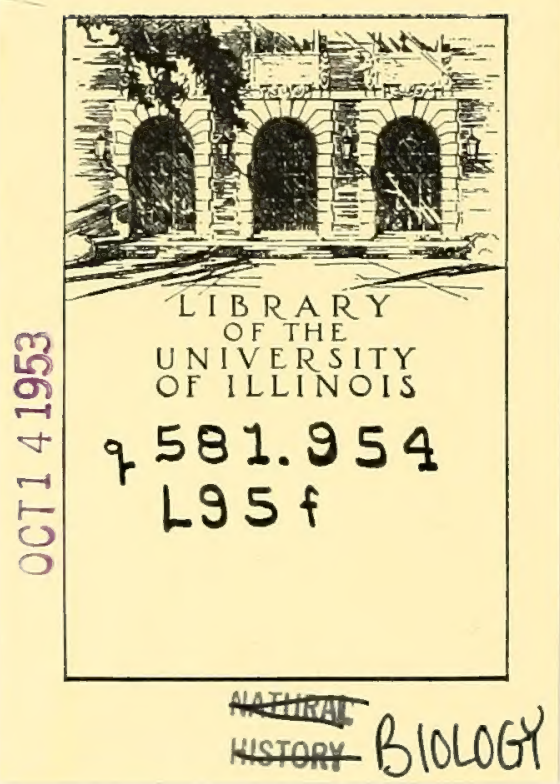


Digitized by the Internet Archive in 2011 with funding from University of Illinois Urbana-Champaign 






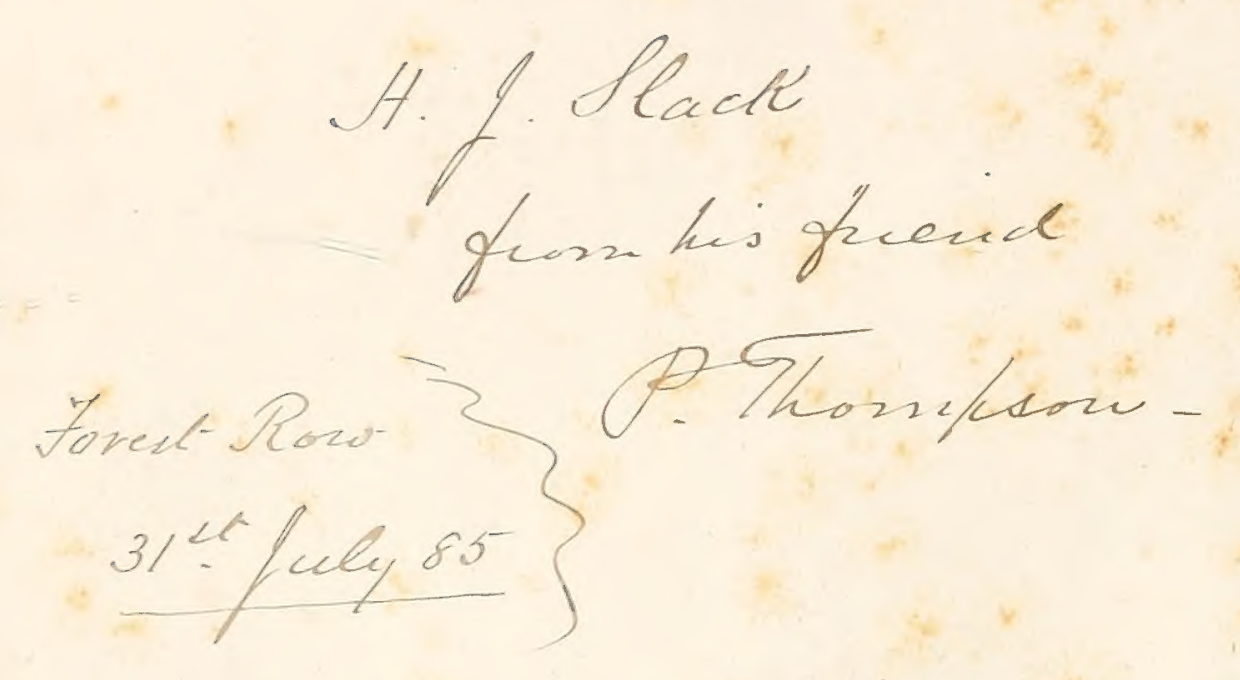




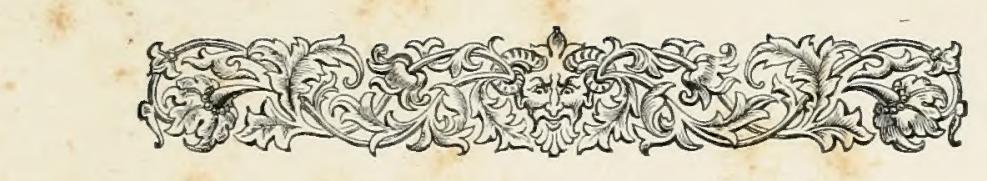

\title{
FHMILIHR
}

\section{IDDIFI, FLOUTERS.}

WITH COLOURED PLATES.

\author{
$\longrightarrow .0400$ \\ BY

\section{LENA LOWIS.}

On either side,

All round about the fragrant marge,

Some dropping low their crimson bell

Half closed, and others studded wide

With disks and tears.

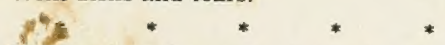

Thence thro' the garden I was drawn-

A realm of pleasance, many a mound,

And many a shadow-chequered lawn

Full of the city's stilly sound

And deep myrrh-thickets blowing round

The stately cedar, tamarisks,

Thick rosaries of scented thorn,

Tall Orient shrubs.

Recollections of the Arabian Nights. TENNYSON.

Ent. Sta. Hall.

Copyright.

\section{LONDON :}

PUblished For THE AUTHOR BY

L. REEVE AND CO., 5, HENRIETTA STREET, COVENT GARDEN.

CALCUTTA: THACKER, SPINK AND CO.

BOMBAY: THACKER AND CO. (LIMITED). 
LONDON :

M. \& N. HANHART, LITHOGRAPHERS. 


\section{ERRATUM.}

Plate No. XI.

For Clerodendron Inerme read Clerodendron Thomsones.

size inu massiveness or the orrginals; but it has been impossible to rectify this without adding considerably to the cost of the book, and thereby making a more pretentious volume than this claims to be.

It is unnecessary to enumerate here the names of authors whose books have been consulted, as they are appended to the quotations.

Notwithstanding its numerous shortcomings, the Author hopes the book may be valued by old Indians, who have, perhaps, spent many happy leisure hours in the culture of these lovely plants, and also by those who delight to hear of the worlss of the Creator in all regions and in all climes.

Chota Nagpore, I878. 
LONDON:

M. \& N. HANHART, LITHOGRAPHERS. 

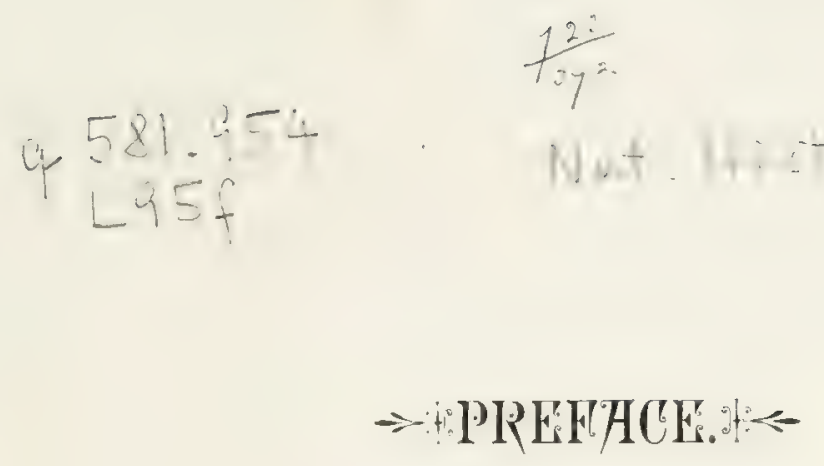

\section{$\rightarrow$ PREHACE. S}

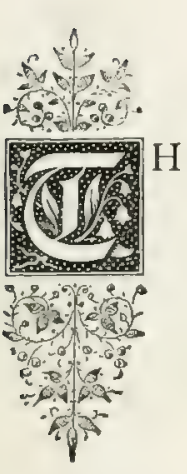

$\mathrm{HE}$ accompanying pages make no pretensions to being either a Manual of Gardening or a Treatise on Botany, but are a simple chronicle of some of the familiar flowers to be met with in our Indian gardens.

To many who have seen the flowers, the plates may appear meagre and unsatisfactory, conveying but a poor idea of the size and massiveness of the originals; but it has been impossible to rectify this without adding considerably to the cost of the book, and thereby making a more pretentious volume than this claims to be.

It is unnecessary to enumerate here the names of authors whose books have been consulted, as they are appended to the quotations.

Notwithstanding its numerous shortcomings, the Author hopes the book may be valued by old Indians, who have, perhaps, spent many happy leisure hours in the culture of these lovely plants, and also by those who delight to hear of the works of the Creator in all regions and in all climes.

Chota Nagpore, I87S. 


\section{N D E X.}

I. Lagerstromia Indica.

II. Musscenda Macrophylla.

III. Plumbago Capensis.

iV. Russelia Juncea.

V. Poinciana Pulcherrima.

Vi. Petrea Strapelia.

ViI. Calistemon Linearis.

ViiI. Hibiscus Rosa Linensis.

IX. Tecoma Jasminoides. , Velutina.

X. Clitoria Ternatea.

Xi. Clemodendron Thomsones.

XiI. Thevetia Nereifolia.

XiII. Duranta Plumieri.

XIV. Quisqualis Indica.
XV. Acacia Farnesiana.

XVi. Thunbergia Laurifolia.

XVII. Poinsettia Pulcherrima.

XViII. Convolvulus Pentanthus.

XIX. Nerium Odorum.

XX. Gloriosa Superba.

XXI. Bougainvillia Glabra.

XXII. Bauhinia Acuminata.

XXIII. Argyreia Nervosa.

XXIV. Euphorbia Bojeri.

XXV. Bignonia Venusta.

XXVi. Barleria Cristata.

XXViI. Quamoclit Pennatum.

XXViII. Opuntia Vulgaris.

XXiX. Beaumontia Grandiflora. 



\title{
LAGERSTRCEMIA INDICA.
}

\author{
NATURAL ORDER, LYTHRACEE.
}

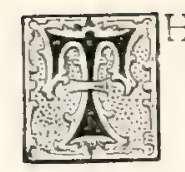

HE illustration now before us exhibits one, perhaps, of the most familiar and most admired of Indian shrubs.

It has been impossible to do justice, either to the exquisite colour or delicate texture of the original, and also, being limited in space, the grand massiveness of the sprays is wanting, but, nevertheless, I trust the foregoing illustration may recall the lovely bush to the memory of those who have seen it, and give a fair idea of it to those who have not been so fortunate.

Owing to the crinkled, crumpled appearance of the flowers, this bush has obtained the name of the "Crape Flower."

Three varieties of the Lagerstromia are much the same in growth and shape of the flowers, but they differ in colour, being pink, lilac, and white. They are all very beautiful, and, when growing in close proximity, make a gay and striking addition to a garden.

From the illustration it will be noticed that the flowers grow in pyramidic heads or sprays quite at the termination of the branches, whilst the leaves, which are oval-shaped, grow thick and close in the centre of the bush, thereby relieving the dazzling colours, and yet at the same time greatly enhancing by contrast the general beauty of the bush.

There is a slight resemblance between the Lagerstrœmia and our English May in growth and style of the bushes, but it does not extend beyond these.

There is a tinge of red on the buds and stalks.

During the cold season these shrubs present a most ugly and forlorn appearance, for, being deciduous, there is nothing to be seen but the bare and barren stems, which form a great contrast to the glory and splendour of a few months before.

Beddome mentions that the wood of the Lagerstromia is valued as excellent timber, and "much used for building, boat-making, ploughs, and axe-handles." He also states that "Lagerstromia Regina has timber of a reddish colour, is tough, and very durable under water, though it soon decays under ground." Quoting from the same authority, I find that in the Madras gun-carriage manufactory this wood is found most serviceable.

From Dr. Brandis, who writes from Burmah, we learn that, with the exception of teak, these trees are considered the most valuable and most useful of all timbers for a variety of purposes.

The season at which the Lagerstromias are at the height of their beauty is during the rains, and it is much to be regretted that, owing to the delicate, fragile arrangement of the petals, their loveliness is but of short duration, for the rain very soon batters and spoils the flowers.

With the exception of the usefulness of its wood the Lagerstromia has no other merits for utility, nor has it any medicinal properties. 


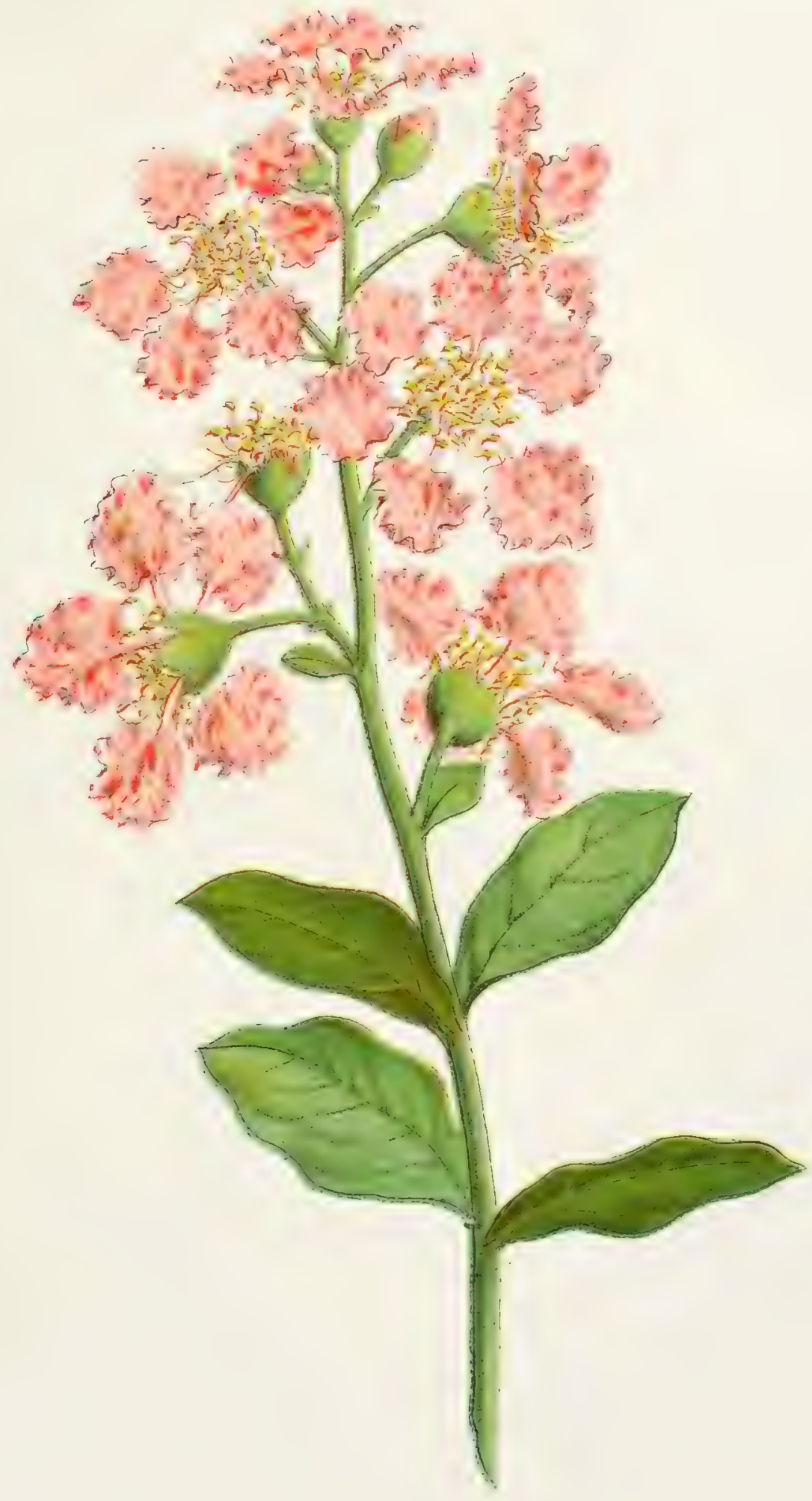






\title{
MUSSCENDA MACROPHYLLA.
}

\author{
NATURAL ORDER, CINCHONACEÆ.
}

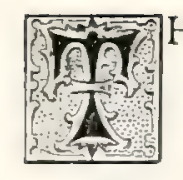

HE subject of this illustration belongs to a genus of rather large shrubs, with heavy dense foliage, of oval-shaped, deep, dull green leaves.

There is very little difference between the species; they blossom during the hot and rainy seasons, and bear numerous corymbs of bright, star-formed orange-coloured flowers.

The hairy white leaves which constitute the principal ornament of the plants are developed from the calyses of one or two flowers in each corymb; they make a pleasing contrast to the dull and sombre green leaves.

The orange flowers are bright and dazzling, but they are small, and, were it not for the white or cream-coloured leaves, this bush would not be much sought for as an ornament to our gardens.

If left unchecked, the Mussœnda becomes very straggling and scandent in its growth, reaching at times over large mango trees, where its creamy leaves and bright flowers are seen to great advantage amongst the shining glossy foliage of the mango.

During the rains its growth is very rapid, and it spreads considerably, forming quite a jungle of any shrubbery or plantation; it is therefore necessary to prune it well in the cold season when it has shed its leaves.

Ferminger mentions that it seeds abundantly, but this is not the case all over India. I have never been able to get any, nor have I noticed young self-sown plants. It takes easily from cuttings, which is the usual mode of propagation.

Roxburgh remarlis that "in some parts of India the white floral leaves are brought to table as an excellent herb."

It is a very woody, hard-limbed shrub, a native of India, and occasionally found in a wild state in the jungle.

The flowers generally grow in pairs, the stems and calyxes being covered with small fine hairs; the star-like flowers surmount a long narrow tube of a pale yellow colour. 


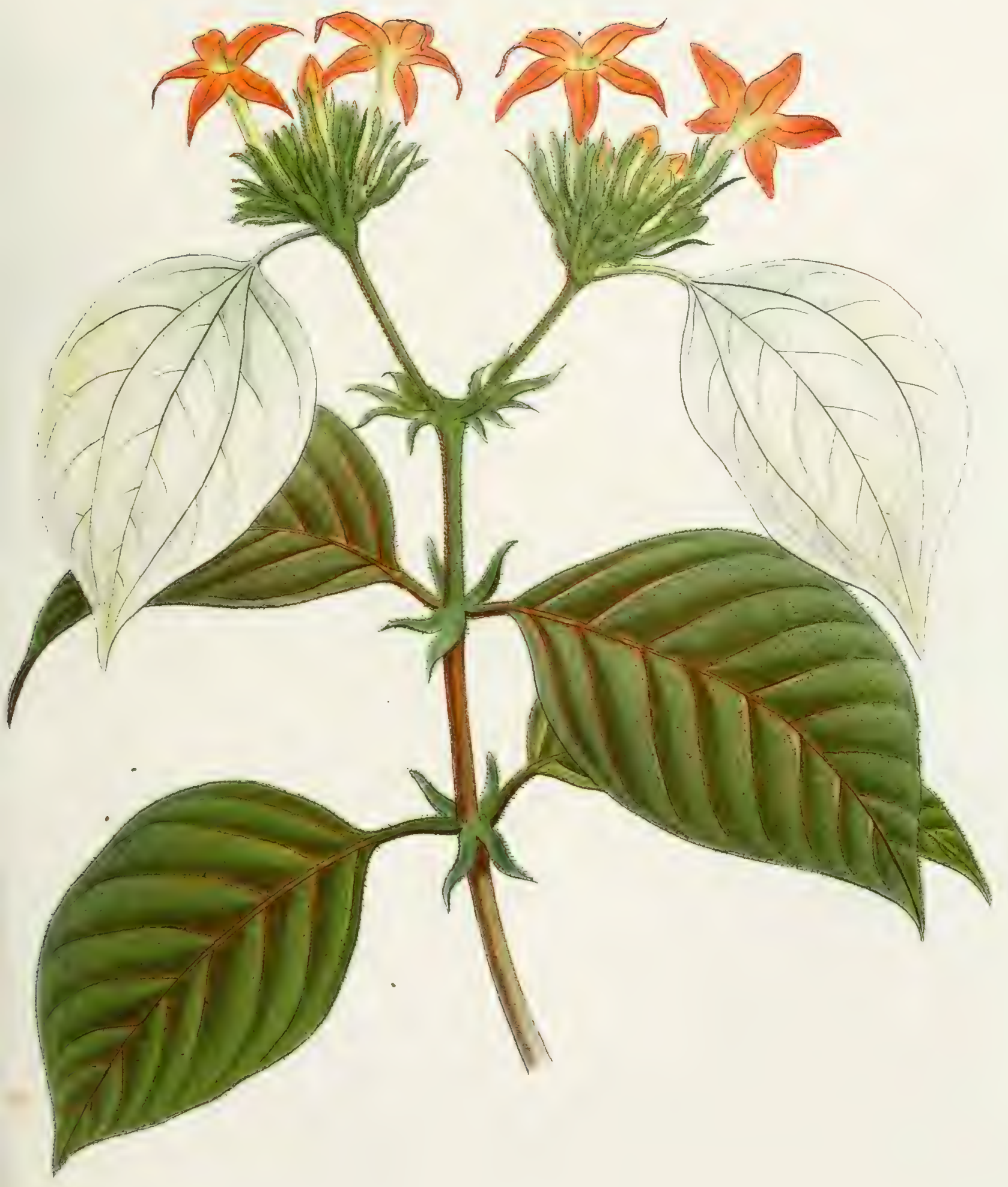






\title{
PLUMBAGO CAPENSIS.
}

\author{
NATURAL ORDER, PLUMBAGINACEE.
}

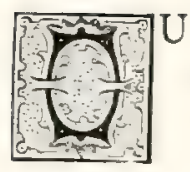

UR present subject is a shrub of prostrate growth, about three or four feet high.

The foliage is arranged in a succession of whorls of lanceolate leaves from half an inch to two inches long, by no means attractive either in shape or colour.

From its untidy, straggling appearance this shrub is not ornamental or pleasing in its growth, and would hardly deserve a place in the garden were it not for its beautiful heads of azure-blue flowers.

The profusion of these lovely blue flowers is the beauty of the plant, and make up in a great measure for its otherwise unattractive appearance.

The Plumbago is a very familiar shrub in all parts of India, and seems to have no favourite locality, but thrives well in all districts.

During the hot weather it may be seen in its greatest perfection, but a few stray heads of blossom may be found at all times of the year.

The form and arrangement of the flowers have aptly been described by Ferminger and others as similar to the Phlox.

The soft mossy look of the buds and calyxes is a great addition to the prettiness of these flowers.

In addition to the present subject there are three varieties of the Plumbago, viz., "Plumbago Larpentæ," "Plumbago Rosea," and "Plumbago Zeylanica." The first of these three is a native of China, and, according to Ferminger, does not thrive in India; the flowers are a deeper blue and larger in size than the subject of our illustration, but otherwise there is a great resemblance between them.

"Plumbago Rosea," as the name suggests, has reddish flowers; they are borne on a spiral head, and blossom in the cold weather. This variety, however, is more delicate and difficult to cultivate than the foregoing.

Ferminger makes the following remarks regarding "Plumbago Zeylanica": "A small, slender, and not very pleasing shrub, bearing at all seasons racemes of small, white, sparkling flowers, very clammy and disagreeable to the touch." This variety is more uncommon than the preceding ones, owing perhaps to its being less showy and attractive. 


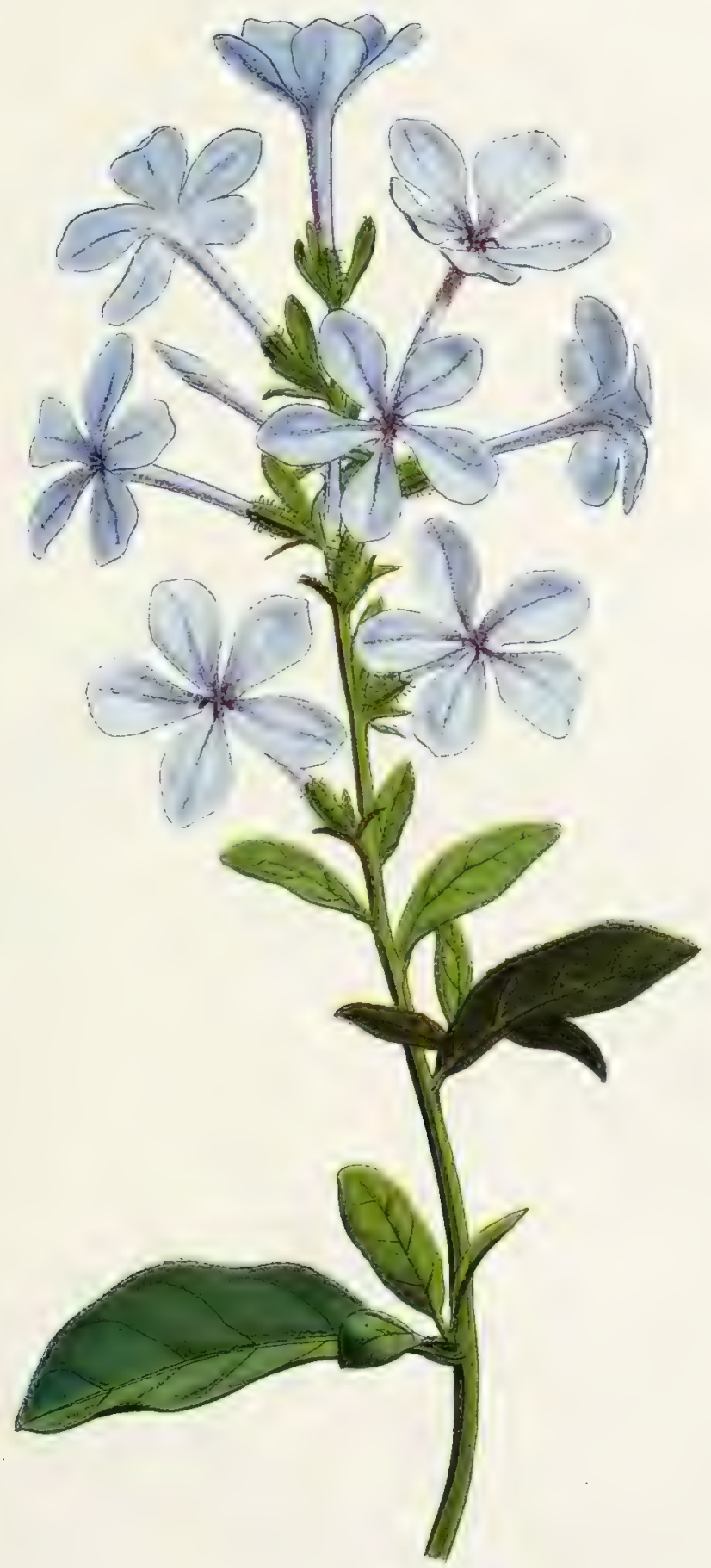

Hanhart, Iru 




\section{RUSSELIA JUNCEA.}

NATURAL ORDER, SCROPHULARIACEÆ.

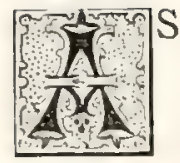

S far as I have been able to ascertain there are only two varieties of this plant met with in India. The "Russelia Juncea," which is depicted in the opposite plate, is certainly the most common, and becomes almost a weed during the rains, when every portion that touches the ground takes root, thereby considerably extending and increasing the size of the original bush.

It is an extremely handsome plant, being of a bushy appearance with tubular bright scarlet flowers, which grow in great profusion on its rush-like stems.

The flowers vary in length from half an inch to an inch, and have a sort of open lip at the termination.

The general appearance is very pleasing, as there are no harsh or angular stems or stalks to offend the eye; but the whole bush looks like a graceful feathery mass of a bright green hue, spangled over with the above-named brilliant tube-like flowers.

It is necessary to prune this bush well when not in blossom, or it soon gets beyond bounds.

It is propagated either by division of roots or by layers, which, as before remarked, take most easily.

This plant is often grown in hothouses in England, but its treatment there is totally different, and would never answer in this hot climate. It is usually placed in hanging baskets, from which it droops in a picturesque manner; but this treatment would be unsuccessful in India from want of sufficient moisture and depth of earth for the roots.

It is a peculiarity about this plant worthy of remark that it has no green leaves of any size or importance; the entire bush, which is about three or four feet high, consists of green reed-like stems upon which the flowers grow.

I have never been able to obtain seeds from the Russelia, though I often watched for the seed capsules to form; but it was only curiosity that prompted me to do so, as propagation is so easy in other ways. From its light and feathery appearance this plant is a great addition to a bouquet, especially when the flowers are out in perfection.

It is a hardy plant on the whole and will grow in almost any soil, but is much improved by irrigation.

It requires a good deal of water, but if allowed to lodge or rest among the roots they very soon rot and the plant is destroyed.

"Russelia Floribunda," the second variety, bears very little resemblance to the foregoing plant; the flowers are the same colour and shape, but are borne in crowded bunches along and at the head of every stem. This variety is also more constantly in blossom.

If grown in pots these plants must be often taken up and the roots divided; but they are much more suited to a border or shrubbery where there is space to show off their handsome feathery appearance. 


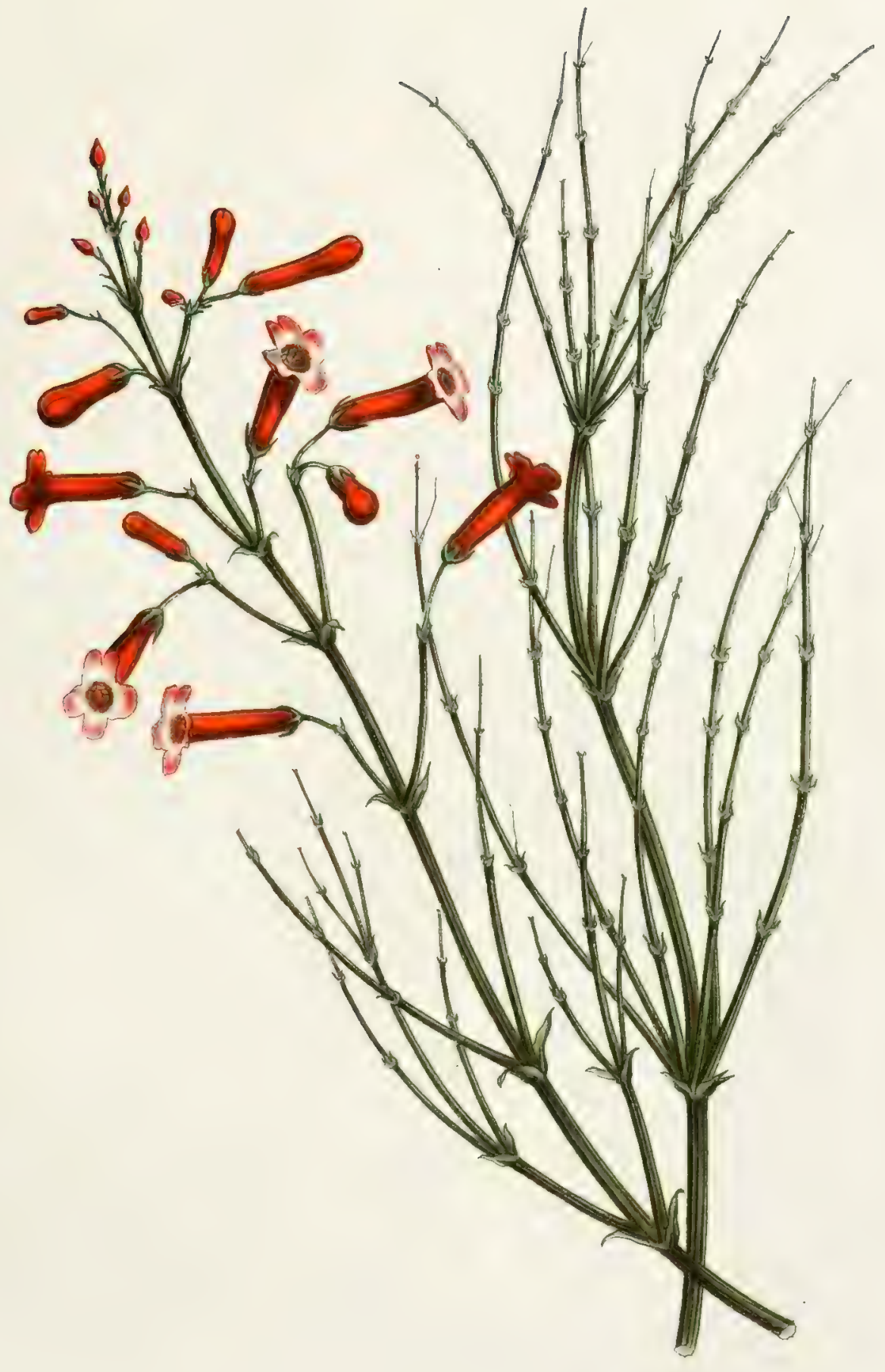






\section{POINCIANA PULCHERRIMA. \\ BARBADOES PRIDE.}

NATURAL ORDER, LEGUMINOSE.

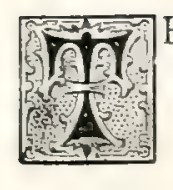

$\mathrm{HE}$ foliage of the plant now before us is, perhaps, as ornamental as the flowers.

From the illustration it will be seen that the leaves are oblong leaflets, set in pairs up a thin stem. When seen in a mass, especially when waving in a breeze, these leaves look very graceful and elegant.

This shrub is in blossom during the hot and rainy seasons; it bears. panicles of bright yellow, or red and yellow flowers, which are in great profusion at the ends of the stems.

The brilliant and gaudy effect may readily be imagined.

There are two varieties, one having pure yellow flowers, and the other yellow marked with red, as depicted in the plate before us.

The buds before expanding are like small round balls at the end of their stalks, about two inches long.

According to the advice given by Ferminger, fresh plants should be raised from seed every year; but my experience does not corroborate this, as a year would hardly allow the shrubs to attain their full perfection.

I find also, from the above authority, that this shrub cannot stand extreme cold, but attains greater perfection in hot climates.

When kept low and thick these shrubs make a capital hedge, from which fact I imagine it is occasionally called "Barbadoes Flower Fence," but when treated in this manner the handsome look of the bush is completely spoilt.

For useful and medicinal purposes this plant is singularly valuable. Major Drury states "that a decoction is made by the natives of the West Indies of the leaves and flowers, which is serviceable in fevers," and the roots and seeds are also used in pharmacy. The wood makes very good charcoal.

The height of the bush is about seven or eight feet; when first expanding the leaves are of a bright, light green. They have been very appropriately compared "to numerous fans floating and waving in the air."

Great care is required in the treatment of young plants. They grow well from seed, but when a few inches high they cannot bear too much heat or too much rain, and also are often killed by the ravages of white ants. 




\title{
PETRÆA STAPELIA.
}

\author{
NATURAL ORDER, VERBENACEE.
}

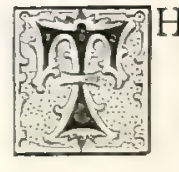

HE plant now under consideration is a native of South America, and is not generally met with; in India it is considered a rare object, but it deserves a place in every garden and repays any trouble that may be taken in its culture.

The lovely, blue, starlike sprays of blossom remind one at a distance of the English creeper named "Wisteria," though the actual form of the separate flowers is totally different.

When not in blossom there is nothing pleasing or attractive in the "Petræa," for the leaves are small and very dry-looking, while the stems are bare and have a barren ugly appearance.

It is an extensively scandent shrub, requiring a strong framework as a support; the trunk often attaining to the size of a man's leg.

It blossoms twice in the year, in February and October, but the former is when the flowers show to the best advantage and the shrub is at its greatest beauty; at that time a more enchanting object the eye could hardly rest upon.

The mass of colour and graceful drooping heads of blossom are most fascinating.

The dark plum-coloured centre adds considerably to the general beauty of the flower; it is raised from the five blue petals, and is the first to wither and fade.

The seed capsules are in the centre of the flower, consequently, when ripe, they drop with the petals, and are not left on the plant as is usually the case.

Plants have been raised by seed, but I always found cuttings by far the most satisfactory, though layers also are successful.

Occasionally young shoots appear from the parent shrub.

It remains in blossom some time, and is one of the choicest Flora that adorn our gardens. 


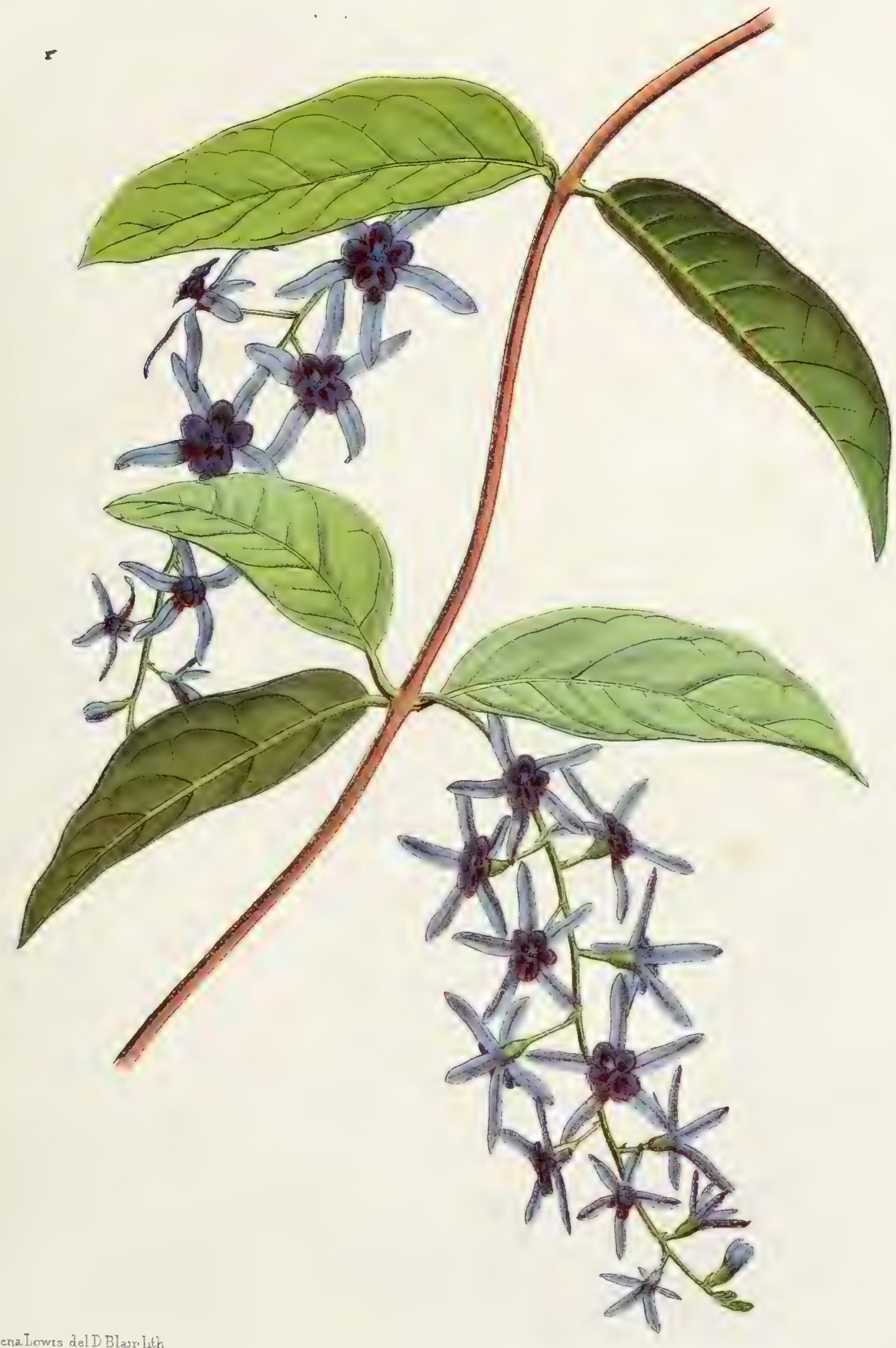

Lera. Lowis del D Blayx Thth 




\section{CALISTEMON LINEARIS.}

NATURAL ORDER, MYRTACEE.

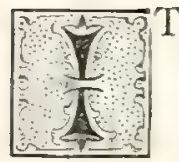

may be disputed whether the above name is the proper one for this plant, but after careful study of various books it seems to me without doubt to be correct, especially as I find it is the name by which people generally know the plant.

Don writes of this genus as follows: "All small trees worthy of cultivation, from the neatness of their foliage and beauty of their blossoms, especially those with splendid flowers of crimson and white."

On close observation this species will be found to have tiny white flowers, the crimson tint being given by the clusters of final elongated stamens, tipped with black.

The effect of these long brilliant stamens is aptly described by Ferminger "as numerous tufts of bottle-brush crimson flowers."

It is a woody, low-growing bush or tree, very pretty when covered with the soft crimson ball-like tufts of blossom.

The buds are small green knob-like balls, and it is peculiar to see them when half expanded, as a few flowers open producing their stamens, while the remainder of the bud is still greenish-brown. I have endeavoured to give this strange look in the picture.

When withering the blossoms look deplorable, as they do not drop off, but the faded stamens lie dejected on the stalk, turning black and brown.

The under side of the leaves is a light, pale yellow, while the upper is dark green, rather shining. The foliage is described by Ferminger as "willow-like."

The seed pods protrude also in a cluster, but I found layers took well and were the best mode of propagation.

The roots spread far under the surface; consequently it is a hazardous undertaking to try transplanting these bushes.

They are of very slow growth, and require little or no pruning.

The beauty of each head only lasts one day, the tender stamens withering at sunset.

I should certainly recommend this shrub to all anxious to have ornamental and curious flowers in their gardens. 


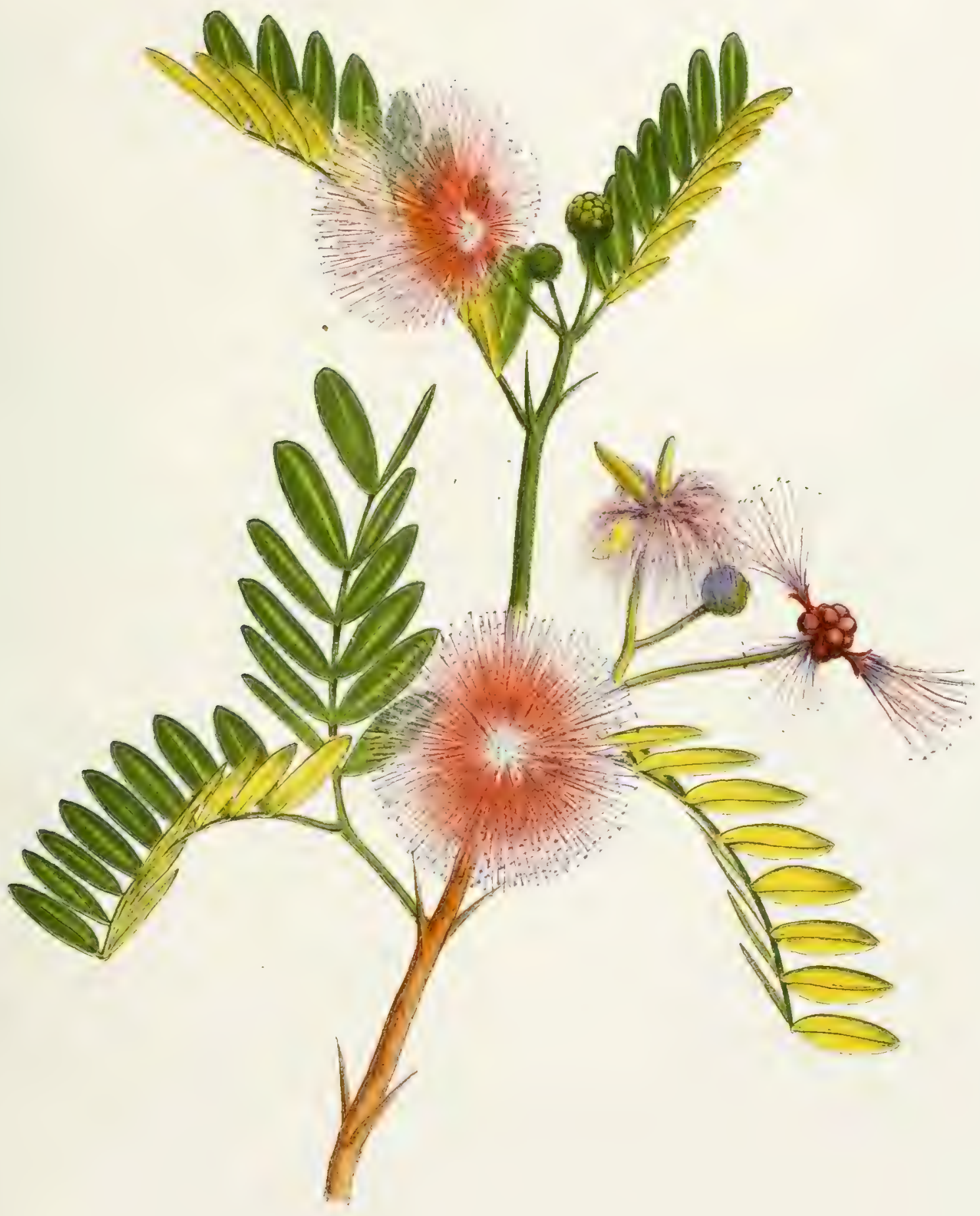






\title{
HIBISCUS ROSA LINENSIS.
}

\author{
NATURAL ORDER, MALVACEæ.
}

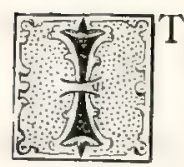

T would be quite beyond the scope of a superficial work of this kind to depict or even enumerate the numerous plants in this genus. They are so associated with India and so well known to all who have lived there that one specimen will recall the others.

The single variety given in the plate is the one most frequently met with; and the gay, cheerful appearance of the bushes, when covered with blossom, may be imagined from the one flower before us.

Common as these plants may be, especially the single varieties, it would be difficult to find more ornamental and showy-looking plants.

The Hibiscus is of the same order as the English Hollyhock, and there is a great resemblance between the flowers of some of the varieties and the much-loved Hollyhock of our English borders; in growth, however, they differ considerably, the Hibiscus being a thick, woody bush.

Roxburgh mentions that the Double Hibiscus is only found in a cultivated state, while the single variety is found wild in Central India. He also tells us "that the English name is 'Shoe Plant,' on account of the juice from the petals of the flowers being used for blacking shoes." I have also heard it stated that the native women dye their hair and eyebrows with the same juice.

"In China," writes Major Drury, "they make these handsome flowers into garlands and festoons on all occasions of festivities, and even in their sepulchral rites."

The leaves are used medicinally, and are said to be very powerful in checking certain diseases.

During the rains the Hibiscus is at its greatest perfection, and many of the flowers would then measure six or eight inches in circumference. They fade very quickly if cut. When several of these gaudy, striking flowers are open at once it is impossible to describe the brilliancy of the bush.

The leaves are small in comparison to the flower; they are smooth, with sharp points, and very serrated edges.

This is such a large and extensive genus that almost every shade of colour and hue may be found in it, and when several varieties are near each other the effect is very lovely, and other plants appear thrown into the shade. 


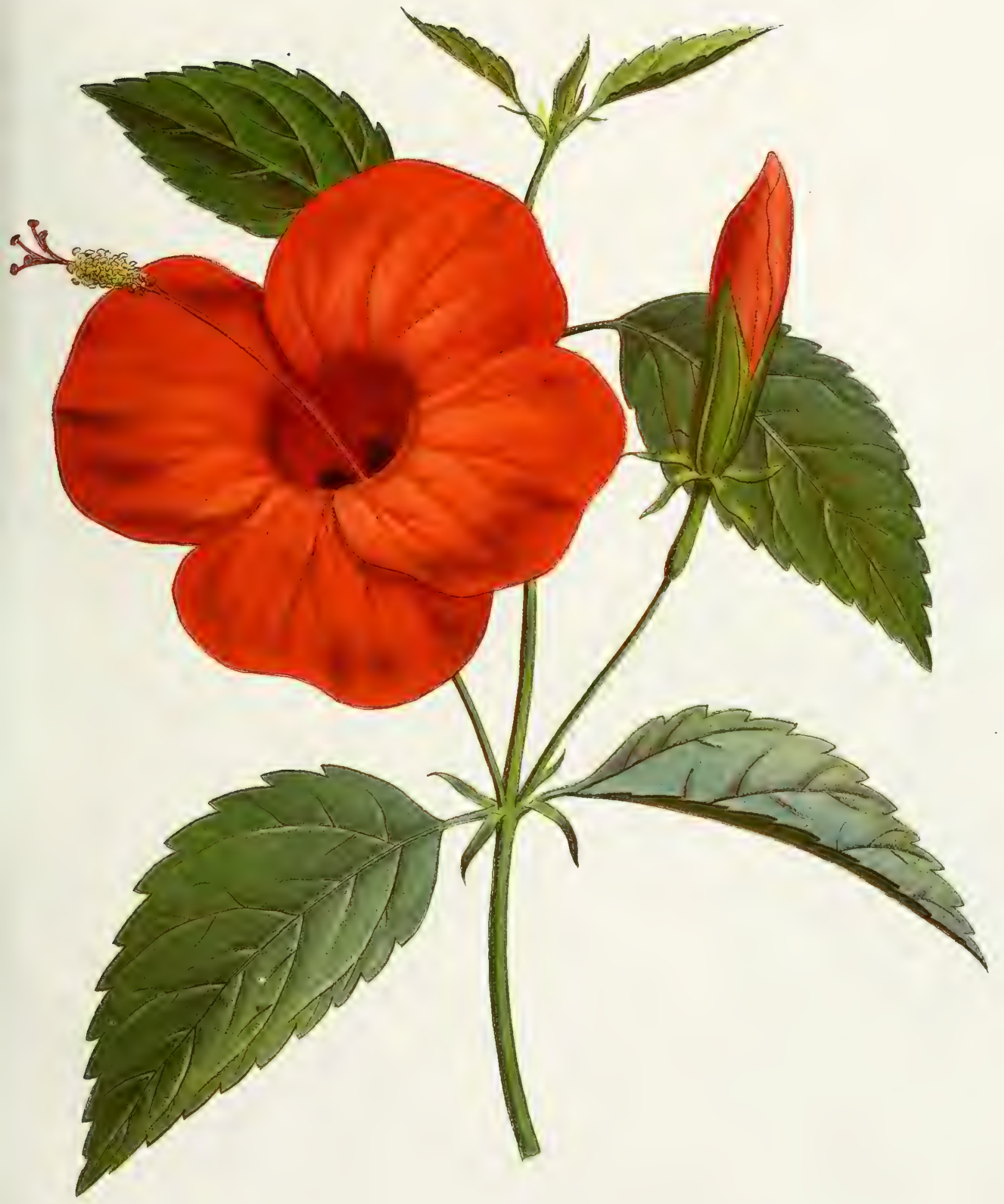






\title{
TECOMA JASMINOIDES.
}

\author{
TECOMA VELUTINA. \\ NATURAL ORDER, BIGNONIACEZ.
}

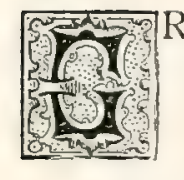

RACEFUL as all the Indian climbers are, it would perhaps be difficult to find any which are more so than the two now before us, the foliage, growth, and lovely flowers all tending to captivate the eye and please the senses.

The glossy light foliage which distinguishes all the Tecoma plants is worthy of notice, and the subjects of our illustration are no exception to the rule.

There are six varieties, two of which are either stunted trees or scandent shrubs, whilst those given in the present plate are unquestionably climbers. "Tecoma Jasminoides," the white variety, is a lovely object with its corymbs of white flowers and deep pink centre; the delicate flowers hang in loose bunches, and droop amongst the shining wax-like foliage.

The foliage, as its name implies, is very like that of a jasmine, consisting of five or seven leaflets, growing in pairs on a thin, green stalk.

"Tecoma Velutina," the primrose-coloured variety, is equally beautiful, except perhaps that the leaves are not quite so graceful.

These flowers are funnel-shaped, of a pale, delicate, primrose colour; they fade very quickly.

The stamens, which grow quite at the back of the flower, have a singular appearance, and, when seen through its semi-transparent tube, look like a spider or some flat insect therein imbedded.

The leaves of this variety are lanceolate and vary from two to five inches in length, serrated at the edges. "Tecoma Radicans" is, perhaps, the commonest variety of these shrubs; it is a sprawling bush with pretty delicate foliage, and bright orange scarlet flowers of a tubelike shape.

The propagation of this variety is more easily accomplished, as it takes root wherever the branches touch the ground.

I am not aware of these plants being mentioned in any botanical book as useful, either medicinally or for other purposes.

To be seen to advantage these plants should be trained to hang over a trellis-work, so that the handsome heads of blossom may be allowed to droop gracefully, whilst the pretty foliage soon covers the ugly wooden frame.

The orange variety spreads rapidly, and requires to be more constantly pruned than the climbers, to prevent it from straggling and choking other plants. In a bouquet the foliage of these plants looks very pretty, but the flowers soon wither when cut. 


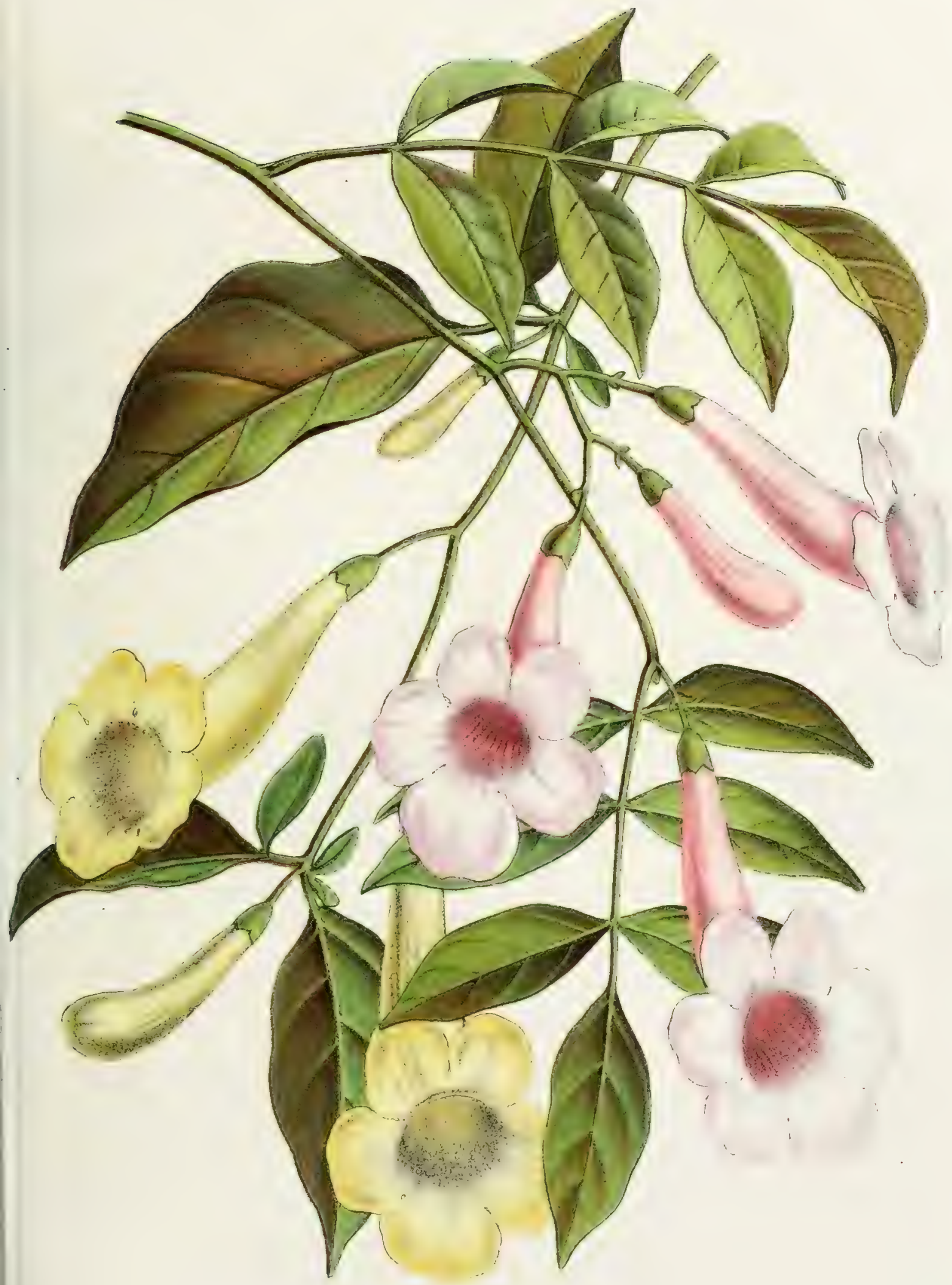






\title{
C L I T O R I A TER N A T E A.
}

\section{MUSSEL-SHELL CREEPER.}

\author{
NATURAL ORDER, FABACEÆ.
}

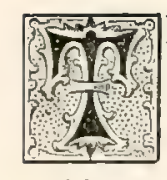

HIS lovely, delicate little creeper is one of the most common and at the same time one of the most ornamental to be found in our gardens.

The leaves are pinnate, with two or three pairs of oval leaflets. In growth it is a rambling and untidy plant, spreading over bushes or anything that comes in its way.

It is particularly slender and graceful, and hangs "its handsome flowers, sparkling among the fine verdant green leaves," in a most charming manner.

There are three or four varieties of this beautiful plant; but with regard to colour, none of them can equal the subject of our illustration. The brilliant azure blue seems deeper and richer when seen amidst the delicate green leaves.

There is a double variety, which is of the same deep blue colour; this is rather a rare species, and I find that Ferminger mentions, "it is unnamed in the Calcutta Botanical Gardens," in the year I864. The Clitoria is in blossom all the year, though during the rains it is much more luxuriant and is then in its greatest perfection.

Roxburgh describes this flower as having the "Corolla supine; banner large expanding under the wings"; he also says, "it is common in every hedgerow all over India, and is in flower the greater part of the year. Its root probably is not inferior to jalap." The powdered seeds are also used medicinally.

The seed-pod is very like a French bean, the seeds are small but very abundant and very soon germinate; young plants come up selfsown, and therefore no trouble is required in propagation. The English name, I imagine, has been suggested by its shape and deep colour, as it recalls the rich look of a polished mussel-shell.

There is no scent from the Clitoria; it is usually treated as an annual, for if left long in one place it becomes a complete jungle and extends in all directions. 




\title{
CLERODENDRON THOMSONES.
}

\author{
NATURAL ORDER, VERBENACEE.
}

" distinctions between the beautiful species of Clerodendron with scarlet inflorescence, will find as ample a harvest of confusion to be reaped as he can desire." To these words every one will assent who has in the smallest degree cultivated these handsome flowers or attempted to classify or enumerate them.

I am a little doubtful as to the correctness of the above name for the species exhibited in the Plate, but after careful study of various books on the subject, the description given of "Clerodendron Thomsones" is the one that tallies best with the plant before us.

It would be difficult to find anything that can surpass the great loveliness of many of the species of this genus; they are also well known, and may be found adorning every garden.

Unlike most of the other varieties, our present subject is a scandent shrub, and might almost be denominated a climber. It requires a support, and will spread over any bush or shrub close at hand.

The stems are a dark, almost purple colour, and the bright scarlet flowers with their creamy calyxes droop most gracefully from the tips.

The extreme elegance and grace of this bush can hardly be imagined, unless once beheld: during the cold weather, when in its greatest beauty, it has a very fascinating and charming effect, appearing like a multitude of creamy bells, tipped with bright scarlet tongues.

It is difficult to procure the seeds of this species, as they are light and soon blown away, but as it takes well from cuttings, there is no difficulty in raising young plants. Many of the other varieties throw up young suckers very abundantly, which should be transplanted to prevent too thick a growth of these plants.

The coral-crimson blossoms and handsome umbrella-like leaves of the other varieties are well known, but the heads of flowers being over a foot in length, they are quite beyond anything but a casual mention in this work. 


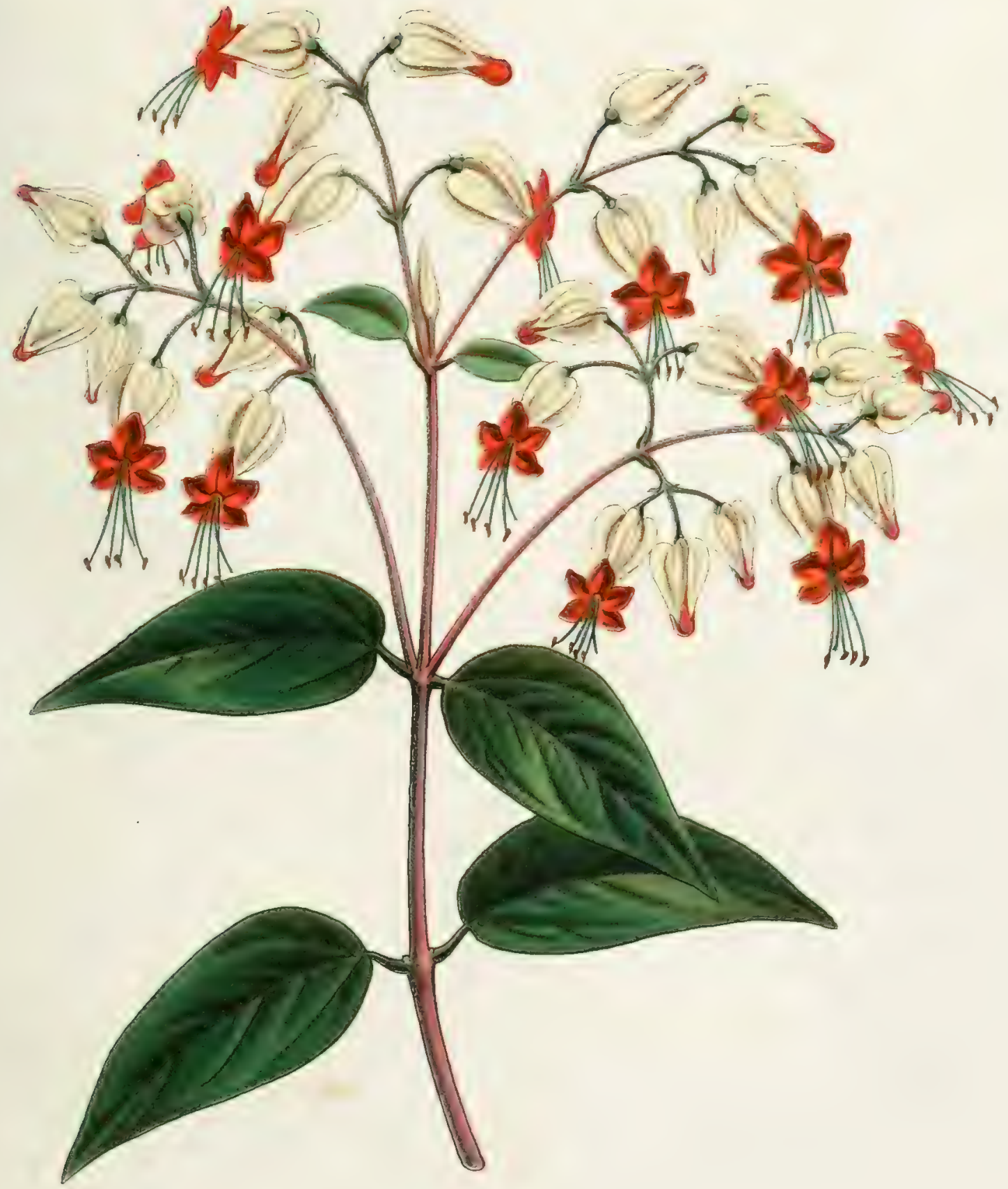






\title{
THEVETIA NEREIFOLIA.
}

\author{
NATURAL ORDER, APOCYNACEE.
}

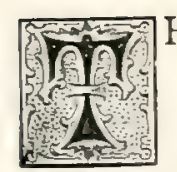

HE Hindustani name for this flower is "Zurd Kurnel," which probably originated in the strong resemblance between its foliage and that of the Oleander, for that is also called by the natives "Kurnel."

The specimen in the illustration is the only one met with in India. It is now a very common shrub in this country, but South America is its native land.

Ferminger describes this plant in the following manner: "It is a small, handsome, spreading tree, from eight to ten feet high; the flowers are thimble-formed and bright yellow." Owing to the leaves and flowers growing at the extremity of the boughs this bush shows to greater advantage if placed in a shrubbery, where its bare stems are hidden by low bushes, and over which it can droop its clusters of shining bright leaves and brilliant flowers.

Being very like a willow in growth, and having no trunk to speak of, each bough appears to spring from the ground separately; like the willow, also, it is often found on the banks of tanks, or overhanging water.

There is a powerful but rather sickly scent from the flowers, which is unbearable to many people, and may account for the Thevetia being seldom seen in a garden and considered only fit for a hedgerow.

Like all the plants of this order, a thick milky juice exudes from any part that is cut or broken; it is sticky and most disagreeable to the touch.

The flowers are very short-lived; expanding one day, they seem to droop and fall off the next, covering the ground with their bright, golden blossoms.

Young shoots are continually springing and shooting up, so that propagation is very easy; and, in fact, if these young plants are not thinned out or removed, a small forest soon arises. It bears seed abundantly, in the shape of nuts, and may also be raised by them.

From these seeds a clear yellow oil is extracted, but its uses and properties are not yet determined.

In Major Drury's valuable book on the "Useful Plants," \&c., he mentions that "the bitter and cathartic bark of the Thevetia is useful as a febrifuge, having the same properties as cinchona." 


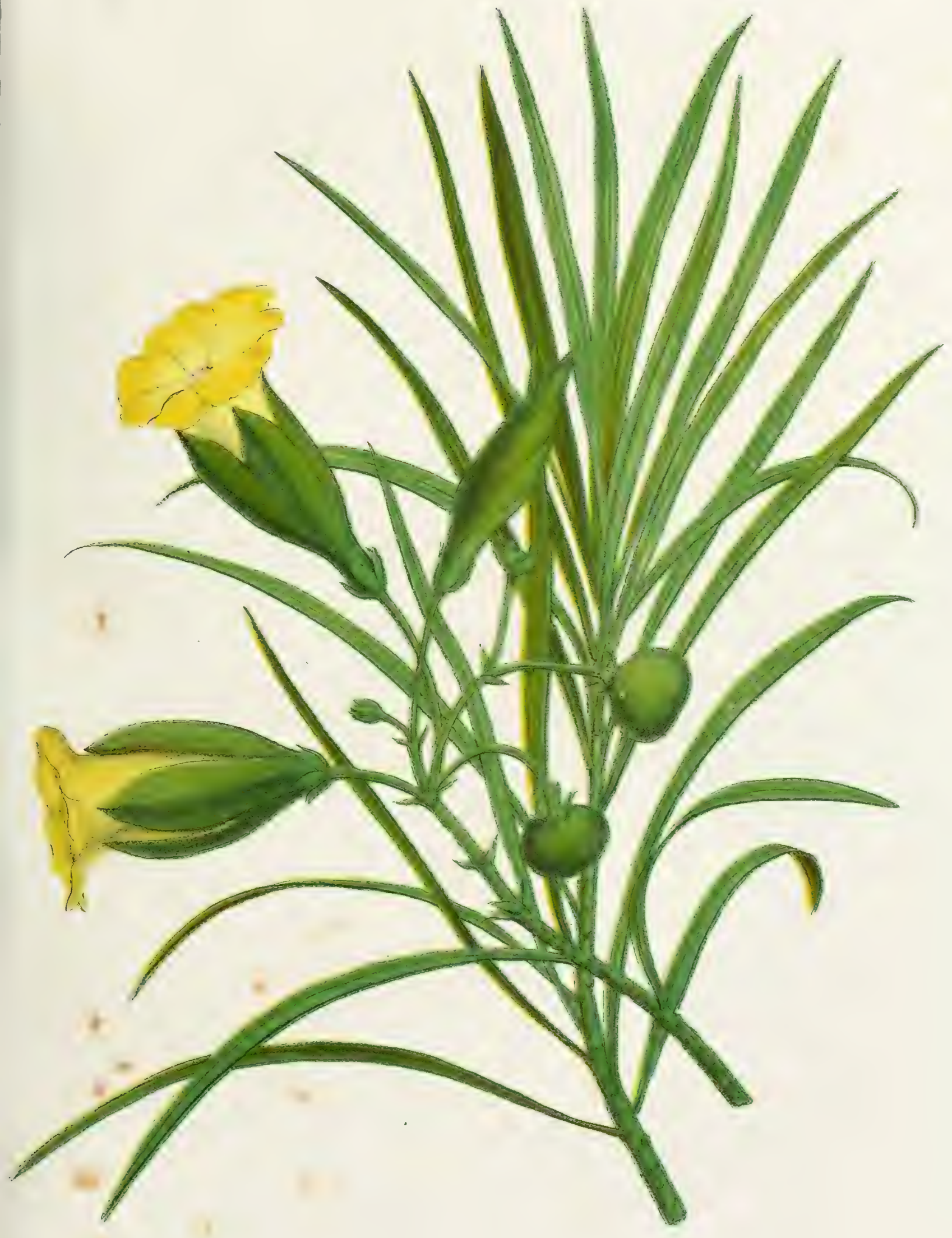






\section{DURANTA PLUMIERI.}

NATURAL ORDER, VERBENACEE.

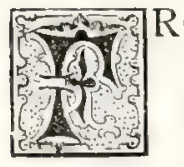

ROM what I can learn about this shrub there are only two varieties of it known in India, but both are very common, and seem to grow in all parts of the country. I have classed it among the shrubs of India, and in so doing am supported by Ferminger and other good botanical authorities; but, notwithstanding this, I have seen it attain to the height of a small tree, and possibly in an uncultivated state it may grow considerably higher and larger still.

It is a showy, pretty bush, growing in a thick compact form, and even when left unchecked it does not get straggling and unsightly as is generally the case with the Flora of this country.

Constant pruning and cutting back, however, improves these bushes, and should be unsparingly administered.

The leaves are bright and shining, and set the flowers off to great advantage. Like many of the flowers of this order, taken singly they are small and delicate, and might be passed over as insignificant; but when taken either in heads, like the ordinary Verbena, or in sprays, as in our present subject, they are both striking and pleasing to the eye.

This shrub looks green and fresh at all times, as not being deciduous it retains its leaves, and when the flowers fall they are succeeded by bright amber-coloured berries, making it a pretty object throughout the year. The berries are about the size of those of Holly, but each berry hangs separate, a short distance from the stem, instead of in a compact bunch upon the stalk, as is the case with Holly.

It is a common practice to make use of the Duranta as a hedge, for which purpose it is admirably suited, being thick and thorny; but it must be kept low, and never allowed to shoot upwards. When treated in the same manner as Box-edging is done at home it becomes almost, if not entirely, impenetrable.

The Duranta is a native of the West Indies, but it thrives in India quite as well as many of the indigenous plants of that country.

It is propagated by either cuttings or seeds, of which latter it bears abundantly.

Soil is of no importance to these plants, as, being very hardy, they grow everywhere.

One botanist, in writing on the "Duranta Plumieri," states it has the perfume of almonds, but I have never been able to discover any scent about either of the varieties; nor is the fact mentioned by other botanical authorities.

The second variety of this shrub is called "Duranta Ellisii," and the only perceptible difference between them is, that the flowers of this one are white instead of blue.

From a utilitarian point of view the Duranta, as far as I know, is of no use or importance; it possesses no qualities to render it of any value either in pharmacy or otherwise. 


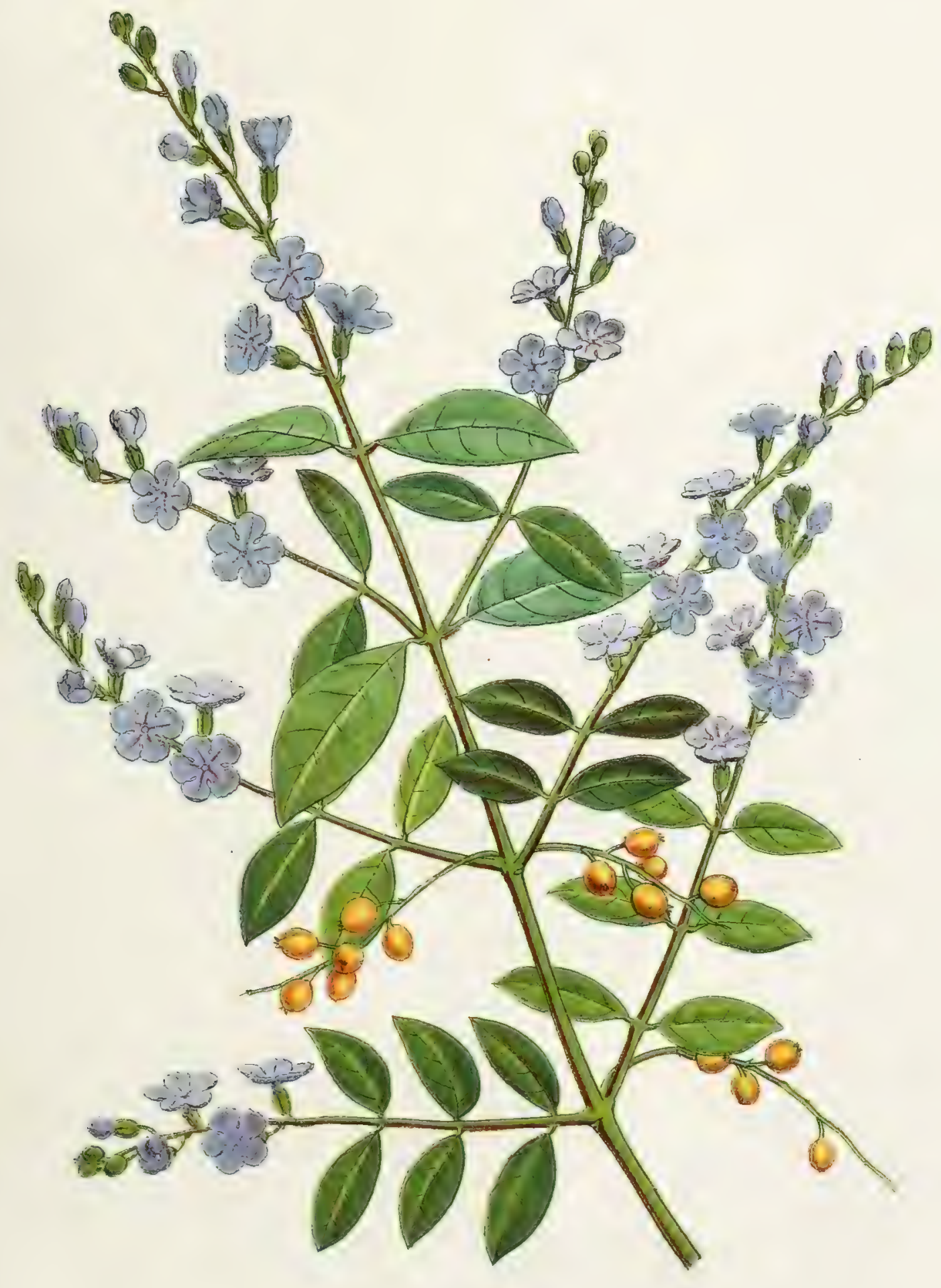






\title{
QUISQUALIS INDICA.
}

\author{
RANGOON CREEPER.
}

NATURAL ORDER, COMBRETACEE.

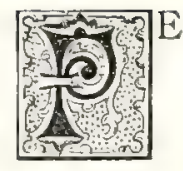

ERHAPS one of the most striking features in Indian horticulture is the number and variety of climbers that are to be found growing in the greatest luxuriance and profusion all over the country.

In the accompanying plate is exhibited one of the commonest and, at the same time, one of the loveliest of these climbers.

It is very luxuriant and rampant in its growth, and requires a strong support, as well as constant and severe pruning.

To all Anglo-Indians this specimen will be well known, used, as it often is, to form a screen to an ugly wall or offensive paling, on account of its being always green and possessing dense foliage.

It is at its best during the hot season, when it affords a beautiful spectacle with its masses of bloom, which, hanging in clusters of rich profusion, completely conceal its trunk and branches. The clusters droop a long way from the parent stem.

This climber, when left long unchecked, will grow to a great height, and has been known to cover the tops of high trees, where the loveliness of its blossoms, mingling with the foliage of those trees over which it roams, becomes greatly enhanced by force of contrast.

From the plate it will be seen that the leaves grow in pairs down the stems, the end ones being of a dark brown or chocolate colour, whilst the general tint of the leaves is that of a heavy, dull green. They are also rough and slightly hairy to the touch.

One of the great peculiarities and sources of beauty of the plant is that the flowers vary in tint. When first open in the early morning they are a creamy white, but as they fade they turn crimson scarlet, so that when the two are combined the beauty of the whole may be more easily imagined than described.

A young tendril or shoot has also been represented in the illustration, and it is worthy of notice that the young leaves have the same reddish hue before alluded to.

The scent of the Quisqualis is very sweet, but it is not always agreeable near a house, and many persons on this account object to the cultivation of it in their gardens. It is very powerful and is perceptible at a great distance.

Chinese Honeysuckle or Rangoon Creeper are both names by which it is known.

In the neighbourhood of Calcutta the flowers are much larger, and wear a handsomer appearance than in other parts of India, which proves that a damp, moist climate is conducive to its perfection.

The seeds of the plant are often used as a medicine. 


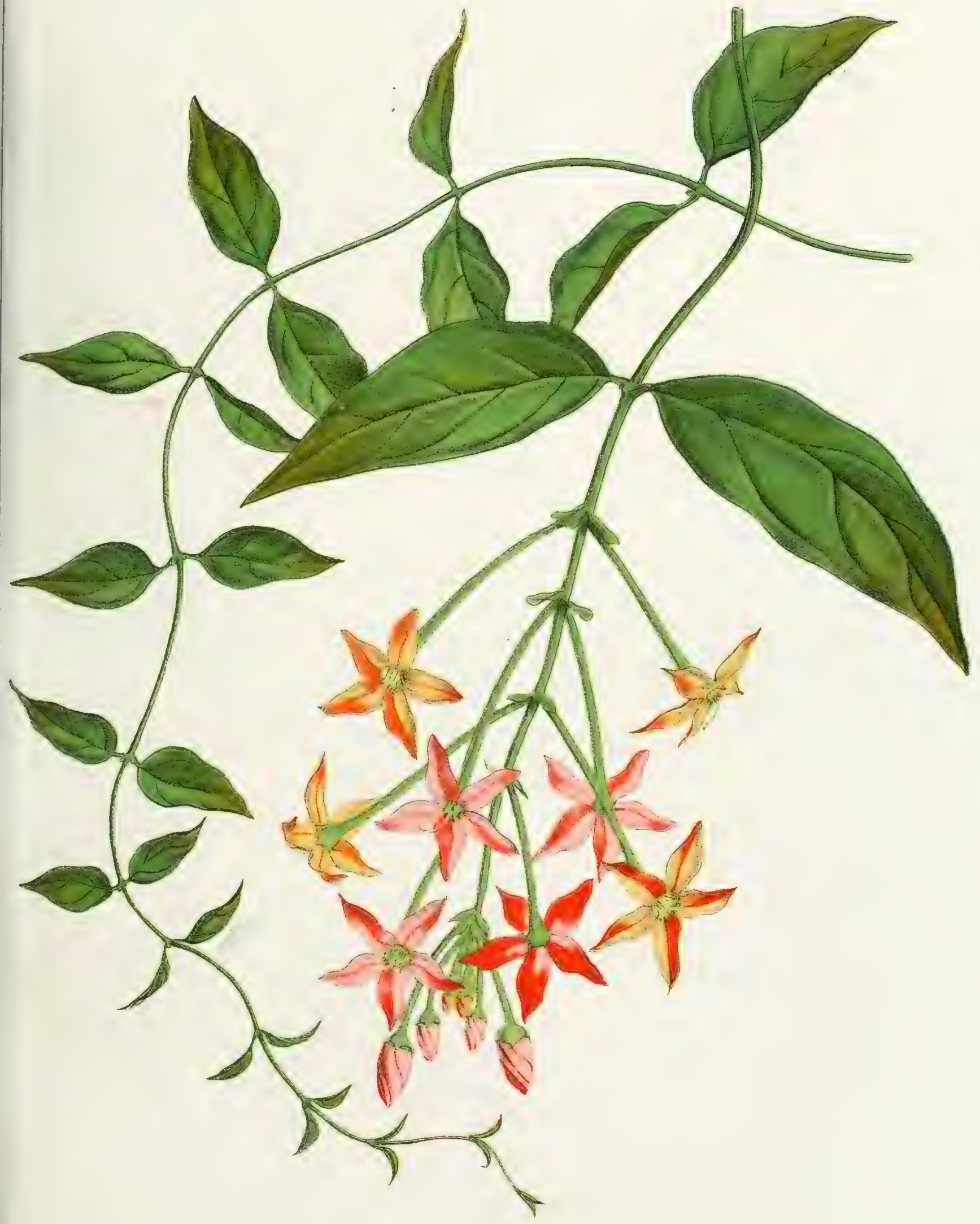






\title{
ACACIA FARNESIANA.
}

\author{
SWEET-SCENTED BÂBOOL.
}

NATURAL ORDER, MIMOSEÆ.

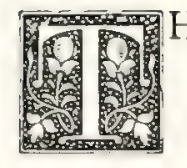

HE accompanying plate exhibits what is, perhaps, hardly a garden flower, but as it is very well known, and is certainly a picturesque object, it may undoubtedly be classed among our familiar flowers.
\end{abstract}

It is a small thorny jungle tree, but during the cold season, when in blossom and covered with its soft bright yellow down-like flowers, it is much to be admired. Ferminger describes the flowers as "tassel-like, and of the size and form of a bullet."

The delightful aromatic fragrance of these flowers is one of the charms of having it in a hedge, and even after the flowers have been cut some time the scent remains. It somewhat resembles the odour of wallflower.

Roxburgh's description of this shrub is as follows: "Shrubby ; thorns, stipulary; leaves, bipinnate; pinnæ, from four to five pairs; leaflets, from ten to fifteen pairs; spikes, axillary; long-peduncled, round; colollebs, polyandrous; legumes, turgid, with two rows of seeds inclosed in pulp."

The natives make use of this plant medicinally, considering the bark efficacious in cases of fever and debility.

The blossoms and fine bipinnate leaves remind us of another species of the Mimoser, viz., the "Sensitive Plant," so well known in this country from the difficulty of eradicating it if it once takes root in a garden. The tassel-like flowers, however, of this are pale pink.

The subject of our plate is constantly planted on the banks of tanks; its foliage is so light and pretty that it makes a great addition to the otherwise ugly and barren sides.

The flowers are soon destroyed by wind or rain, but when in full blossom fresh ones appear to burst open in such rapid succession that the blaze of colour is perpetual and unvarying.

The different species of Acacia are so numerous that it would be futile to attempt to enumerate them. Many are natives of Australia, where, I hear, they are remarkable for the exquisite beauty of their flowers and foliage.

In Ootacamund a few of the above varieties are found to thrive well, but they are not suited to the climate of the plains.

The few that are indigenous to India are not attractive or pleasing, being chiefly wild jungle bushes. 


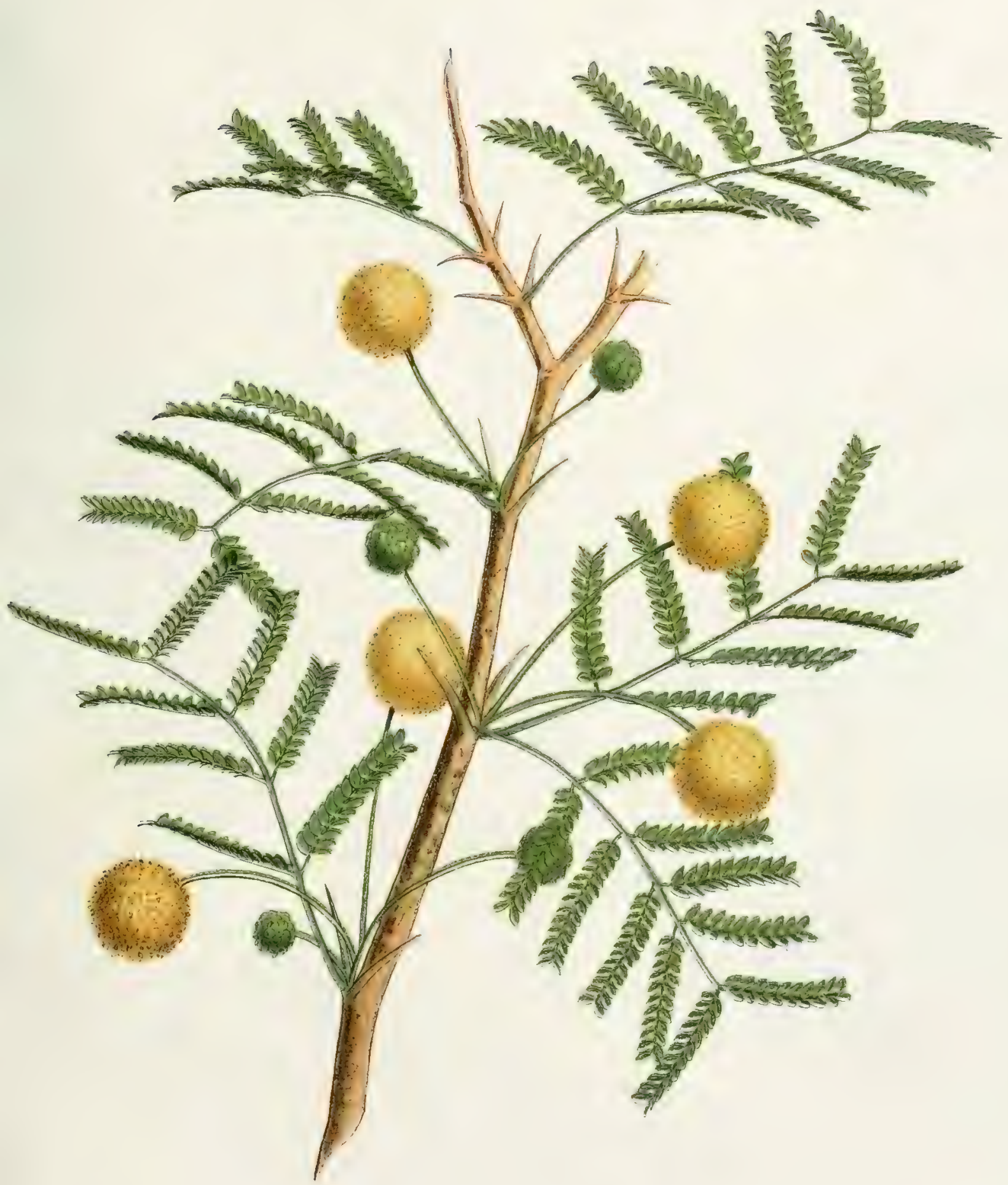






\title{
THUNBERGIA LAURIFOLIA.
}

\author{
NATURAL ORDER, ACANTHACEÆ.
}

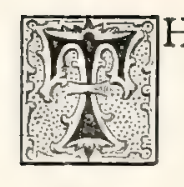

HERE are numerous plants of this order in our Indian gardens. They have all lovely, showy flowers, and deserve a conspicuous place in every parterre.

The mode of treatment is much the same for all the varieties, that being, according to Ferminger, "frequent renewal, transplantation to fresh soil every fall or so, and close cutting in when the flowering season is over."

All the varieties of Thunbergia are essentially climbers, and are very luxuriant and dense in their growth, sometimes covering "the loftiest trees with a curtain of foliage so dense as when seen from a distance to present the appearance of some ivy-clad ruin."

The plant before us is a native of Burmah, but is now quite acclimatised to this country.

The white variety is very common, and may be found in hedges in an uncultivated state. None of the varieties of this plant have any scent.

The capsules of the seeds are all of a remarkable beak-like shape; the seeds germinate quickly.

The soft lavender tint of these flowers is their great beauty, the lower lip being marked with a darker shade; they are very short-lived, and fade immediately on being plucked.

"Thunbergia Laurifolia" is too rampant to be placed anywhere but in a garden, but the buff-coloured variety with a dark puce centre often forms a pretty and effective decoration to the verandah, when planted in a small tub with a bamboo circular trellis for it to twine amongst.

If the seed is planted at the beginning of the rains the young plants will blossom well that year, though in a cultivated state it can be induced to blossom all the year round. 


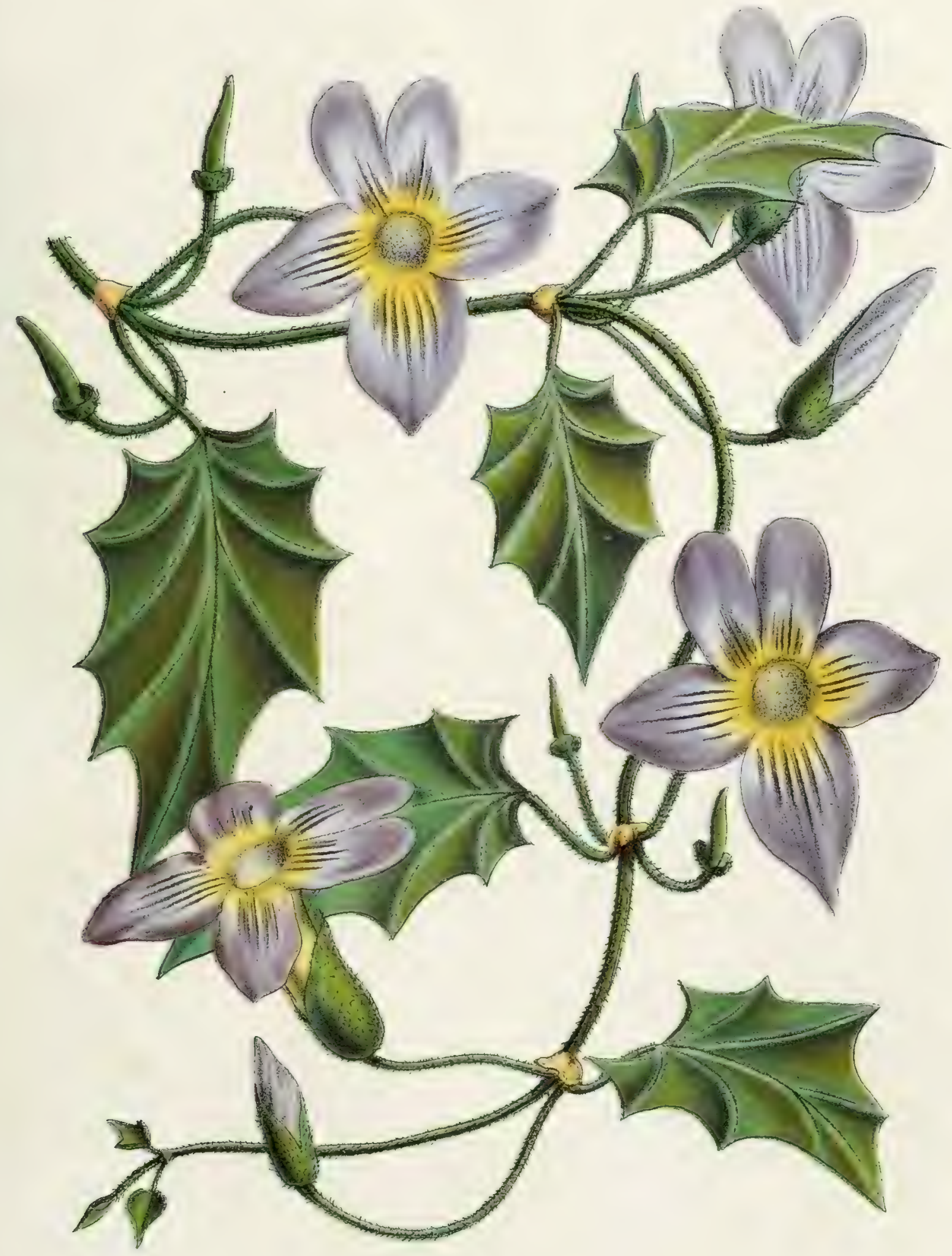






\title{
POINSETTIA PULCHERRIMA.
}

\author{
NATURAL ORDER, EUPHORBIACEE.
}

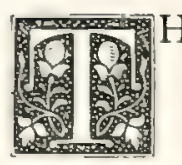

HE accompanying flower will be known in England as a "stove" or hot-house plant, but the blaze of colour can never be imagined from one or two plants seen in this way.

It is one of India's most showy, most gaudy, and most familiar flowers, at least as far north as Agra, where it may be seen growing in the gardens of the Tâj.

The shrub grows to eight or ten feet; it is an untidy, spreading bush, which requires much cutting back after it has blossomed.

The flowers are insignificant, about the size of a pea, bright yellow, and surrounded by large, crimson, bractial leaves, which are the striking part of the bush; they are limp and "fleshy" to the touch.

During the cold season these brilliant leaves are in full splendour and make a border very gay; they are often used to enliven Christmas decorations, as Holly is at home.

As a rule the green leaves are very seldom to be seen with the bright red bractial ones, but when grown in shade I have noticed the two adorning the branches at once, and this is a great improvement.

I find Ferminger mentions that this plant is a native of Mexico.

It is very easy to propagate, as it takes quickly from cuttings.

The milky juice of all the Euphorbiacer is to be found in the Poinsettia. I have never met any other variety, but Ferminger mentions one with greenish-white leaves; he, however, says, "it is not a striking plant." 


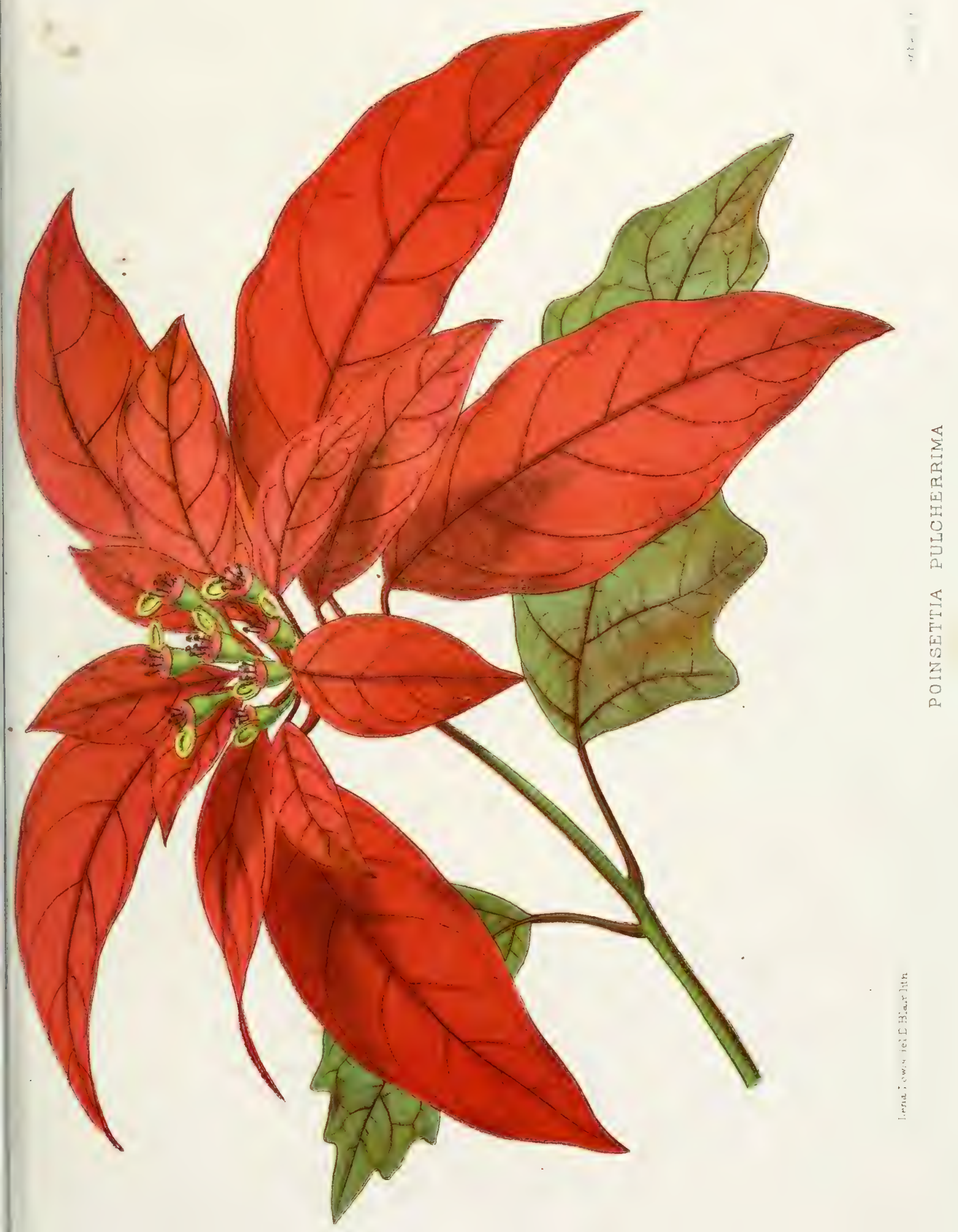






\section{CONVOLVULUS PENTANTHUS.}

NATURAL ORDER, CONVOLVULACEE.

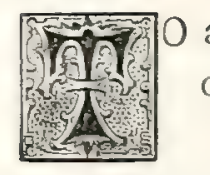

amateurs and learners of botany the differences and distinctions of the Ipomaa and Convolvulus tribes are very puzzling.

The shape of the flowers, the style, growth, and general appearance of the plants are so similar that it is only those who have studied minutely the construction of the flowers who can define the distinction.

The above name is the one usually given to this fascinating creeper by the generality of people, but Ferminger mentions that "it is commonly" called "Ipomæa Semperflorens." "

It is an annual, blossoming in the cold weather, when it is a lovely sight with its bright azure-blue flowers spangled over the green leaves, and often hanging in graceful festoons from a trellis or archway.

The young shoots are of a tender, pale green, tinged with pink, slightly hairy; the flowers grow at the end of thin, long stalks, several buds being in a cluster.

The thin, twining stems twist themselves into a "gigantic tangle," and add much to the free, natural look of the plant; it requires a support, and does not thrive well if left to trail on the ground.

It is a common plant about Calcutta, and $I$ have seen it in great beauty in Chota Nagpore.

The stamens are small and black. The throat is flatter than most of the Convolvulacex and is pure white. The flower has no scent and is only useful as an ornament to the garden. It seeds profusely and can also be propagated by division of roots.

The flowers wither and droop very quickly, but are soon replaced by other buds opening, and at noon this little creeper presents a lovely sight with its blaze of blossom open to the sun. 


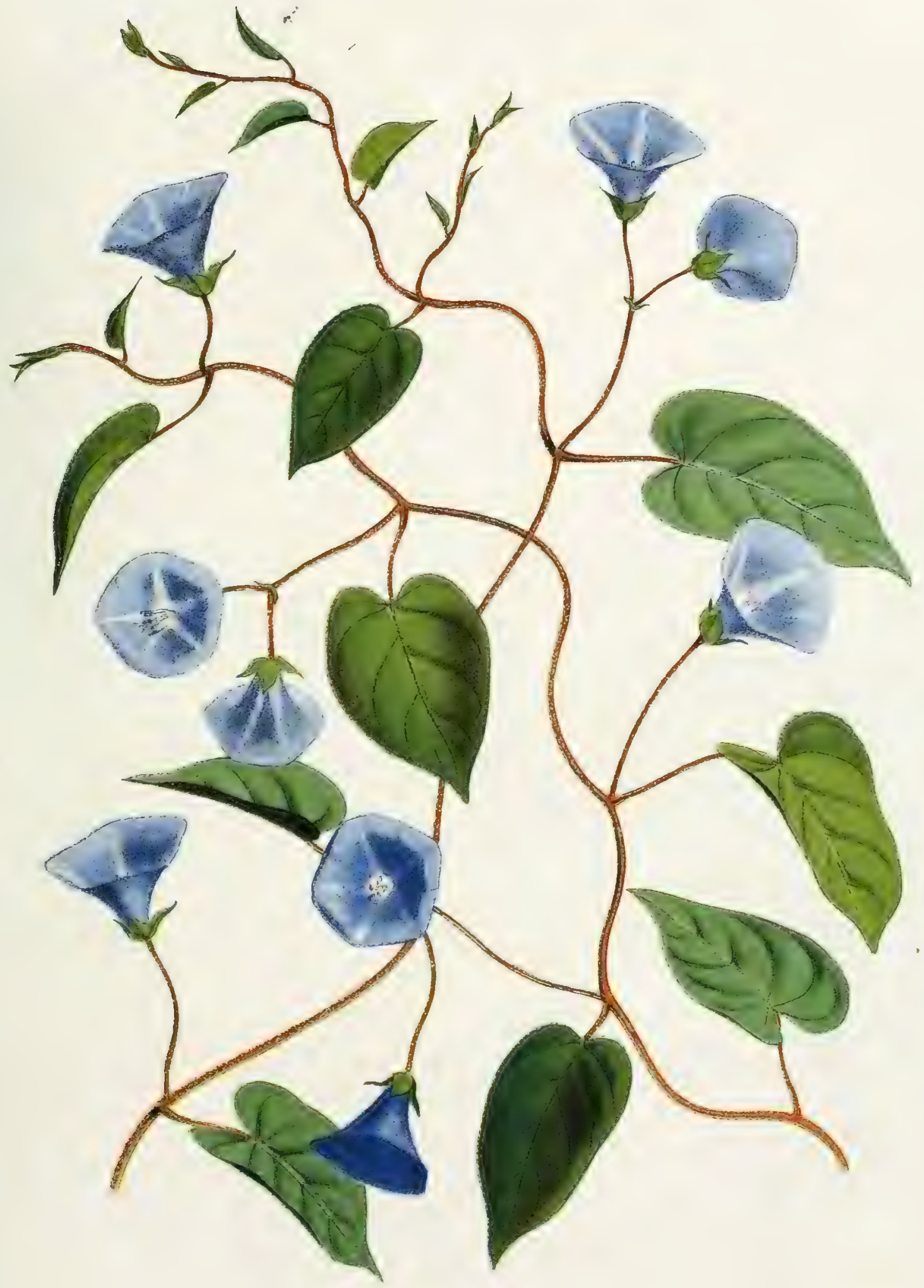






\section{NERIUM ODORUM. \\ OLEANDER. ROSE-BAY. \\ NATURAL ORDER, APOCYNACEE.}

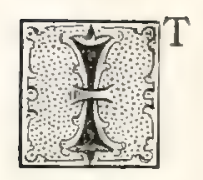

would, perhaps, be difficult to find a plant better known, or more familiar to the eyes of Anglo-Indians, than that in the accompanying plate.

It is seen in its greatest perfection in the Upper Provinces, also in the Deccan; but still it would be difficult to find any garden in India where one species or the other was not thriving.

There are many varieties, single and double; but the single pink one is certainly the most common, and the double white equally rare.

Ferminger thus discribes this bush: "A large spreading shrub, six to eight feet high, throws up from the ground its numerous rod-like stems, upon the summit of which is borne its foliage of narrow lanceolate leaves, surmounted by a profusion of large cheerful flowers."

During hot weather the Oleander is in most luxuriant blossom, especially when planted at the border of a tank or jheel. It requires no care, and is easily propagated by layers or cuttings. It also yields seed abundantly.

Ainslie mentions that this shrub has many medicinal properties, and that "the root itself taken internally is a poison."

It is also mentioned in Powell's "Punj Plants" "as containing a poisonous resin in the root, also in the bark and flowers."

The milky juice which exudes, when a leaf is broken or the stem injured, will be well known to all who have once attempted to pluck any part of the plant; it is of a milky whiteness, but is sticky and disagreeable to the touch.

I have never seen these plants attain any larger dimension than "a large spreading shrub," but I find several species mentioned by Roxburgh as "middling-sized trees," and three or four as "climbers," or "twining" "scandent shrubs."

"Nerium Coccinæum," he says, "in its native soil grows to be a large timber tree: the wood white, remarkably light, but firm and much used by turners to make palkees, \&c., where light strong wood is required."

From the same valuable source I again quote, regarding the "Nerium Pisidum": "An extensive, perennial, woody climber, a native of Silhet in Bengal. Its bark contains a quantity of fibrous matter, which the natives of the country use as a substitute for hemp. In steeping some of the young shoots in a fish pond in order to accelerate the removal of the bark, and cleaning the fibres, many, if not the whole, of the fish were killed, hence the specific name."-Roxburgh's "Flora Indica."

From the leaves of another species, Roxburgh attempted to make indigo, picking the leaves when first opening; he has written a treatise on the subject; but whether the industry has ever been extensively developed I have never heard.

The growth of the shrub depicted in this plate has well been described as a "cluster of rods," each comes singly from the ground, and if growing in the shade they are often drawn up to a great height before expanding into leaves and flowers. 


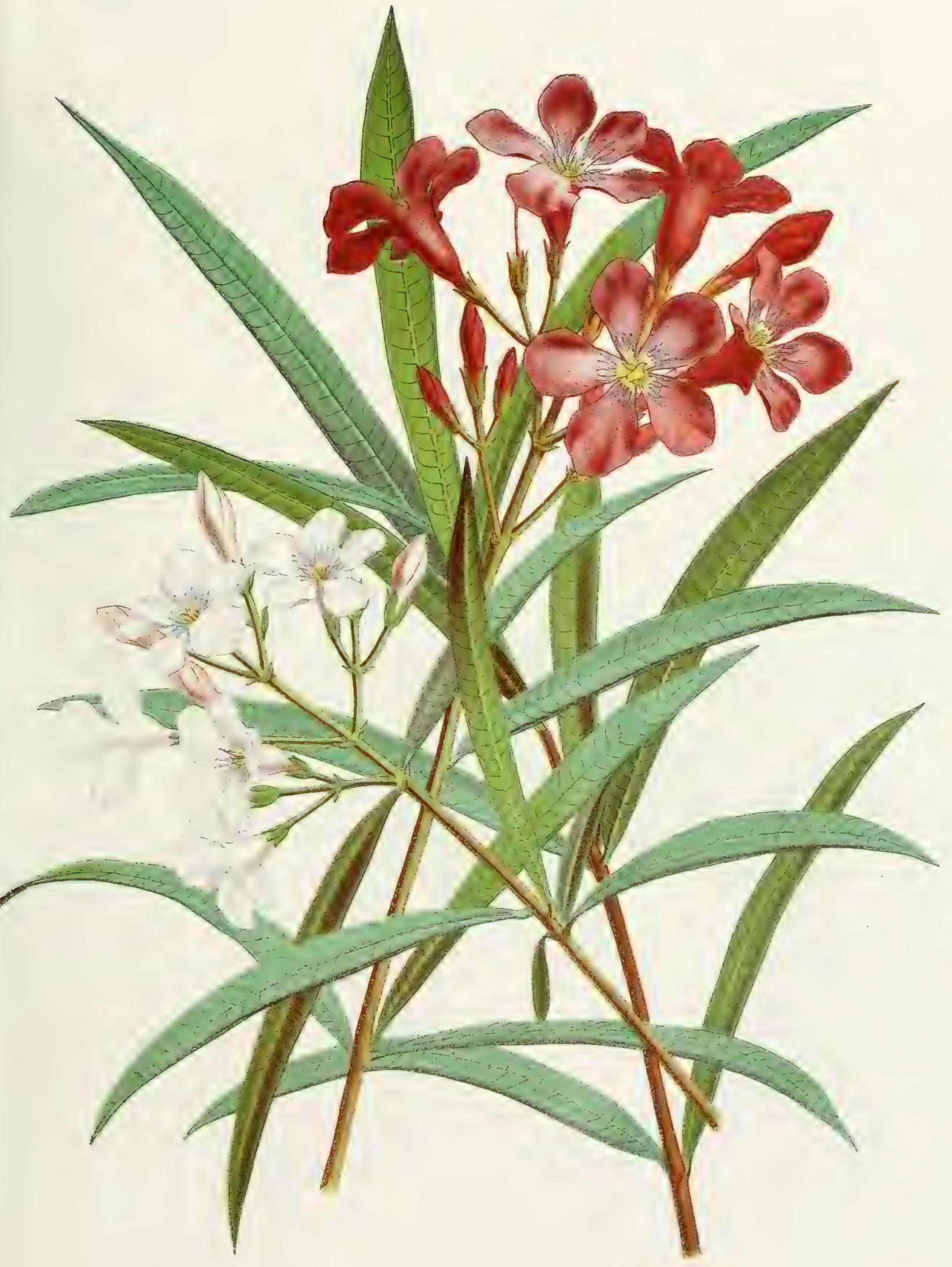






\section{GLORIOSA SUPERBA.}

NATURAL ORDER, LILIACE王。

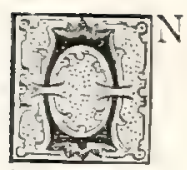

NE of the most charming objects in our gardens during the rains is the above plant; its variety of gay colours-bright yellow, crimson, and chocolate-mingling in luxuriant profusion with its shining green leaves.

It is a bulbous root, and is a native of most parts of India, growing wild in the jungles, where it may be seen in great beauty growing over the forest trees.

During the winter the roots lie dormant, springing up again directly the rains set in.

It is necessary to give it some support, or the weight of its numerous blossoms and luxuriant growth drags it to the ground.

The leaves are lanceolate, ending in a tendril of a vivid green; the stalks are also bright green, very smooth and shining.

I append Ferminger"s description of these flowers: "Bears during the rains curiously formed flowers of long, narrow, inverted, twisted petals, one-half deep crimson and one-half primrose colour on first opening, but afterwards becoming altogether crimson."

The propagation of the Gloriosa is very easy, as, like many of the Liliacer, the bulbs multiply quickly; in fact, when one plant is introduced into a garden it very soon spreads in every direction, and often appears where it is not wanted.

"A salt is prepared from the roots of this lily, by repeated washing and grinding, the white powder being bitter to the taste, but, when mixed with honey, it is used medicinally."

"This plant may be known to some by the name of 'Country or Wild Aconite,' as the native practitioners say it possesses the same properties as the "Aconitum Ferox." (Drury).

The root is a virulent poison.

There is a great enemy to the young shoots of the Gloriosa in the shape of a bright green caterpillar; so great are the ravages of these creatures, and so much do they appreciate the juicy, succulent, new shoots, that if not watched and taken off they will leave the poor plant a bare stalk.

I cannot find more than this one variety mentioned by any botanical authorities as growing in India. 





\title{
BOUGAINVILLIA GLABRA.
}

\author{
NATURAL ORDER,' NYCTAGINACEÆ.
}

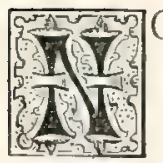

OTWITHSTANDING the many familiar flowers we have already noticed, there will hardly be one better known or admired than the one now before us.

It is so associated with Indian horticulture, and is such an ornament to almost every garden, that no work of this kind would be complete without it.

There are three varieties of this peculiar and lovely shrub, but the one in the illustration is decidedly the most desirable to have in a garden, as it is in constant blossom.

"Bougainvillia Spectabilis" only flowers in February and March.

The appearance of these shrubs is dull and heavy, so far as the foliage is concerned, for they are a dark blue-green, rather hairy and very numerous.

At first sight the bush looks as if covered with a mass of magenta leaves, but on close inspection this proves to be a mistake.

The flowers themselves are small and of a pale yellow colour, and the brilliant magenta that is the ornament of the bush is from the bracteal leaves which envelop the flowers, for there are generally more than one growing out of the same stalk.

When in full blossom the beauty of the bush can well be imagined, affording, as it does, a perfect blaze of colour set off by the dark green leaves.

These plants are very easily propagated by cuttings, either in sand or light mould, but making layers is equally successful.

There is no perceptible difference between the varieties when they are in blossom, as they are all then handsome attractive bushes.

It has often been remarked that Indian flowers are of a more gaudy and resplendent colouring than those English ones, and the specimen before us bears out this idea.

The brilliancy and vividness of the colours must be very striking to those who have not been long in the country.

All the varieties of this plant are very common in India, and may be seen in nearly every garden, where they grow in great luxuriance, especially in Calcutta.

From the plate it will be seen that the flower is a small yellow star at the end of a long narrow tube. One of the distinguishing features of this specimen is that it has thorns all up the stems.

There is no seed to be obtained from these plants that I am aware of; the flowers drop off without forming any.

This particular kind was known only in the Calcutta Horticultural Gardens until quite lately, but the other varieties are common all over India.

It grows well in any soil, but whether indigenous to India or not has never been ascertained.

It possesses no medicinal properties. 


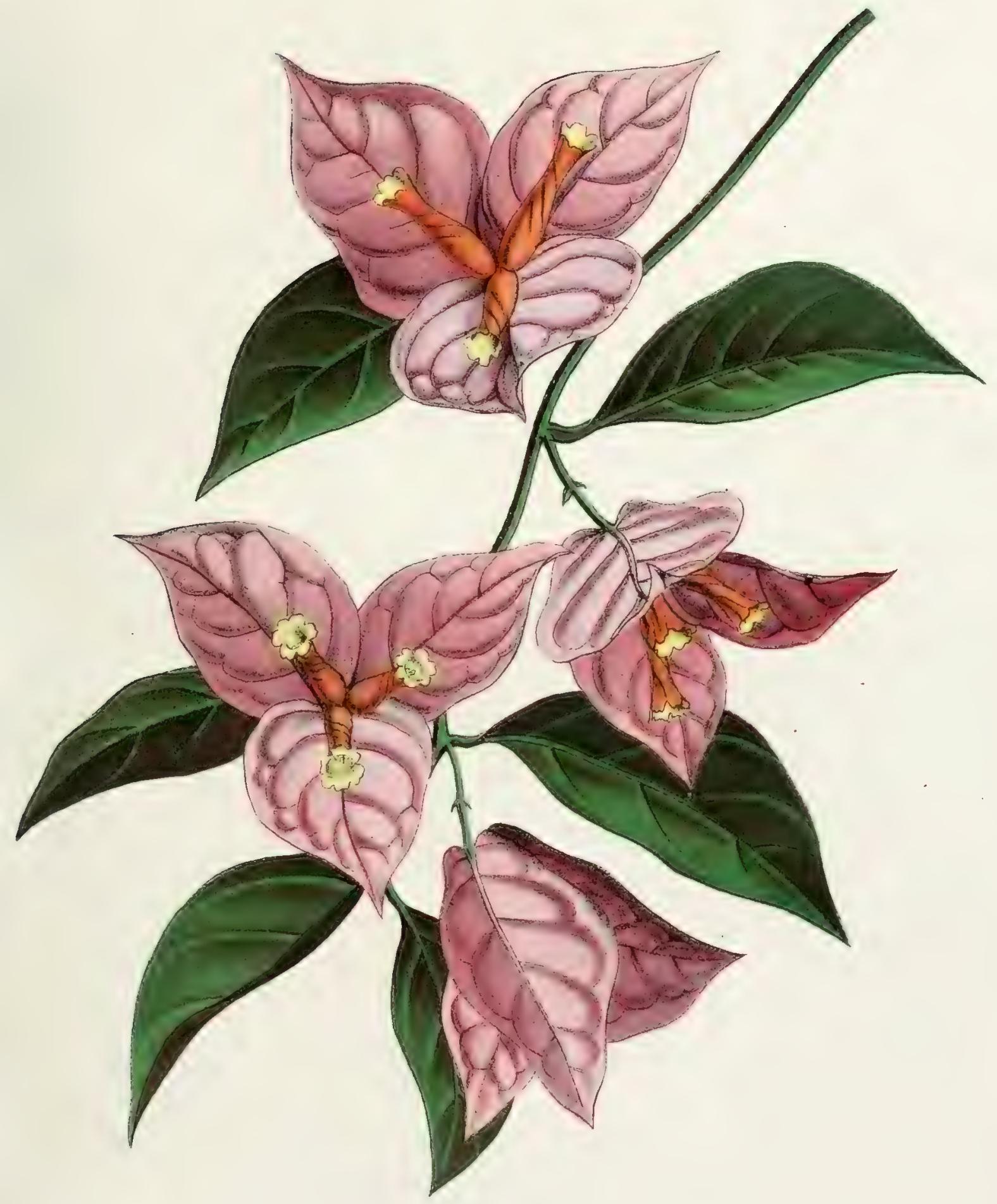






\title{
BAUHINIA ACUMINATA. MOUNTAIN EBONY.
}

\author{
NATURAL ORDER, CESALPINEÆ.
}

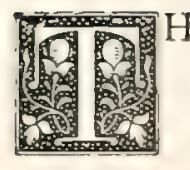

$\mathrm{HE}$ plant now before us belongs to a very extensive genus, all the varieties of which are remarkable for the peculiar form of their leaves, which are like two oval leaflets united at the base. Ferminger tells us that the genus, "in consequence of this twin-like union, has been fancifully named after the two brothers Bauhin." They were well-known French navigators. The variety depicted in the plate is a shrub or small tree about ten feet high, nearly always in blossom, being a pleasing object with its numerous pure white flowers.

There is little resemblance between the flowers of the various species of this extensive genus, but they are all exquisitely beautiful, both in colour and form.

"Bauhinia Variegata," called by the natives "Kuchnâr," is a large tree, having a trunk about the size of a man's body; it blossoms in February, and is then an object of great splendour. The flowers are purple and white, large and handsome, and having a great resemblance to those of a pelargonium. Many of the species have sulphur-coloured flowers speckled with purple.

Both medicinally and economically the Bauhinia plants are invaluable. "Bauhinia Tomentosa" Drury mentions as being used by doctors, while the leaves of various species are also valuable for a decoction made from them. The seeds are eaten, and said to be a tonic.

One of the n:ost remarkable of this genus is, I think, "Bauhinia Vahlii." It is a climber of great extent, covering tree after tree with its large leaves, until a whole wood or "Tope" becomes shaded by it. The flowers are cream-coloured with purple spots, and hang in spiral-like bunches. The trunk of this species was the thickness of a man's thigh in our garden, and the leaves I have sometimes seen nearly a foot in diameter.

"In the northern districts of the 'Circars' the leaves are sold in the bazaars for various purposes, such as plates and packages. Ropes are made from the bark. The natives boil and then beat it, which makes it soft and pliable. The ropes have been occasionally used for suspension bridges over the mountain torrents in the Himalayan valleys." (Rogh. Fib. Plants.)

I find Roxburgh has described this variety under the name of "Bauhinia Racemosa," and says: "It is a native of all the mountainous parts all over India, where it runs over the highest trees." $\mathrm{He}$ also mentions that the seeds are flat, smooth, and brown. They are eaten raw; when ripe the taste is like that of cashew nuts. 


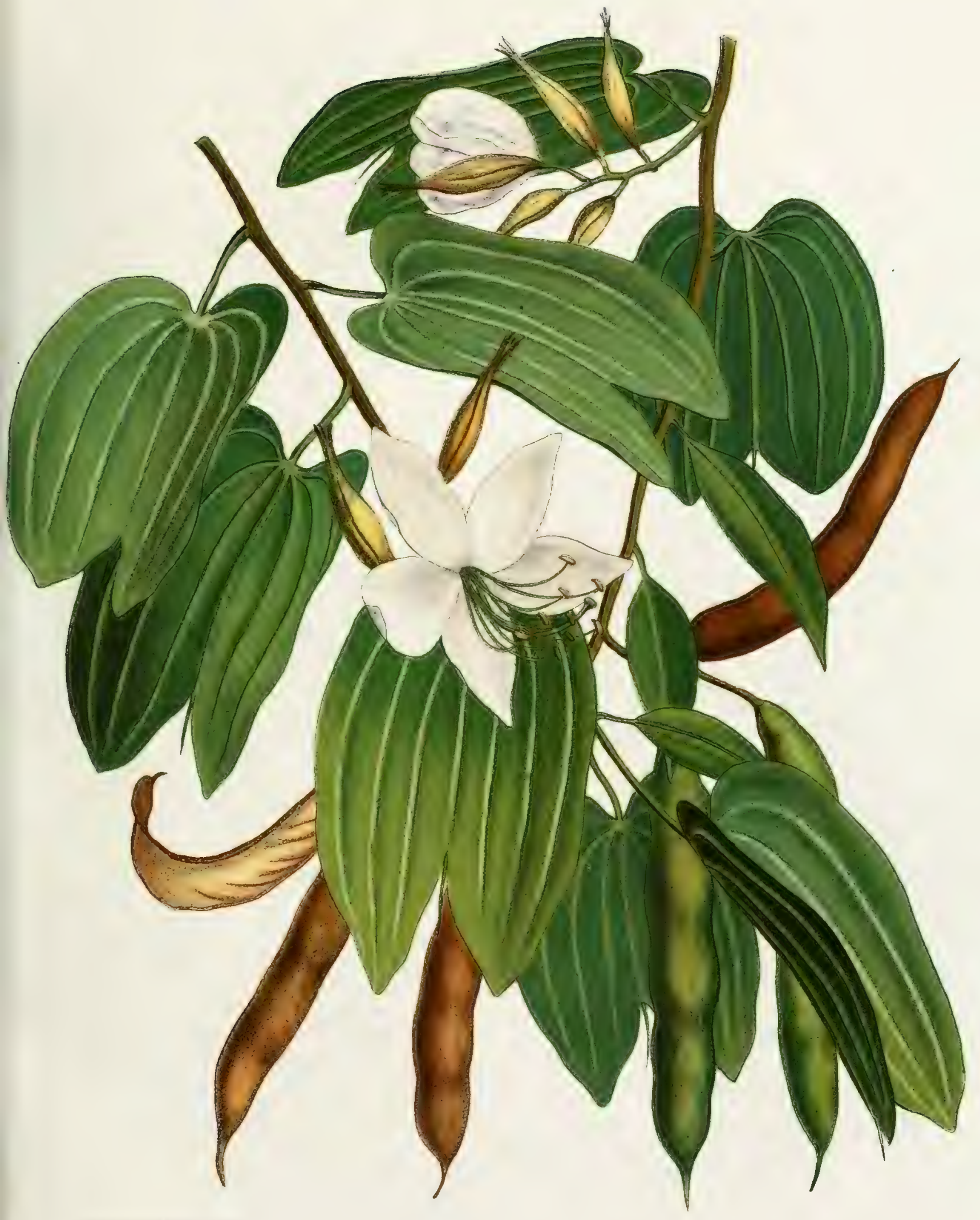






\title{
ARGYREIA NERVOSA.
}

\author{
ELEPHANT CREEPER.
}

NATURAL ORDER, CONVOLVULACEÆ.

HE English name of this plant gives a very fair idea of the size and magnitude to which it grows. Ferminger has briefly described its luxuriant and massive growth as follows: "It is quite unmanageable in a garden unless it can be trained up some tree or outhouse."

Roxburgh has a description of this plant under the name of "Lettsomia Nervosa," and mentions a rather strange occurrence, viz., that he " had some seeds sent him from England called 'Convolvulus Speciosus," but which produced this identical plant. Stigma, \&c., perfectly the same as in the original Bengal plant."

It is a native of forests and hedges, and is one of the largest species of convolvulaceæ known.

The leaves are heart-shaped, and grow to a large size; they are smooth on the upper side, with parallel veins, and have a beautiful silky down underneath. The stems also are covered with silky down, and are of a pretty cream colour.

The umbels of the flowers are deep and very large. They generally grow in bunches, and the "bractes" "many, large, oval, white, waved, pointed, and caducous." (Roxb.)

It is these white, crinkled-looking bractes which are one of the characteristics of the plant. They form a beautiful contrast to the dark handsome flowers.

It blossoms in Bengal during July and August, and seeds profusely.

I have seen it growing over a skeleton shed made of cross bars of wood, but during the time it was at the height of its perfection the shed had the appearance, when inside, of being thickly thatched, from the luxuriant and heavy growth of this plant.

During the cold weather it casts its leaves and looks equally bare and deplorable.

Major Drury mentions that this plant grows in the Malabar forests and in hedges in the Peninsula. He also states, quoting Ainslie and Gibson, that it is useful in pharmacy, the native doctors making different uses of the upper and under parts of the leaves.

For industrial purposes the "Elephant Creeper" does not appear to be conspicuous, as far as I can ascertain. 


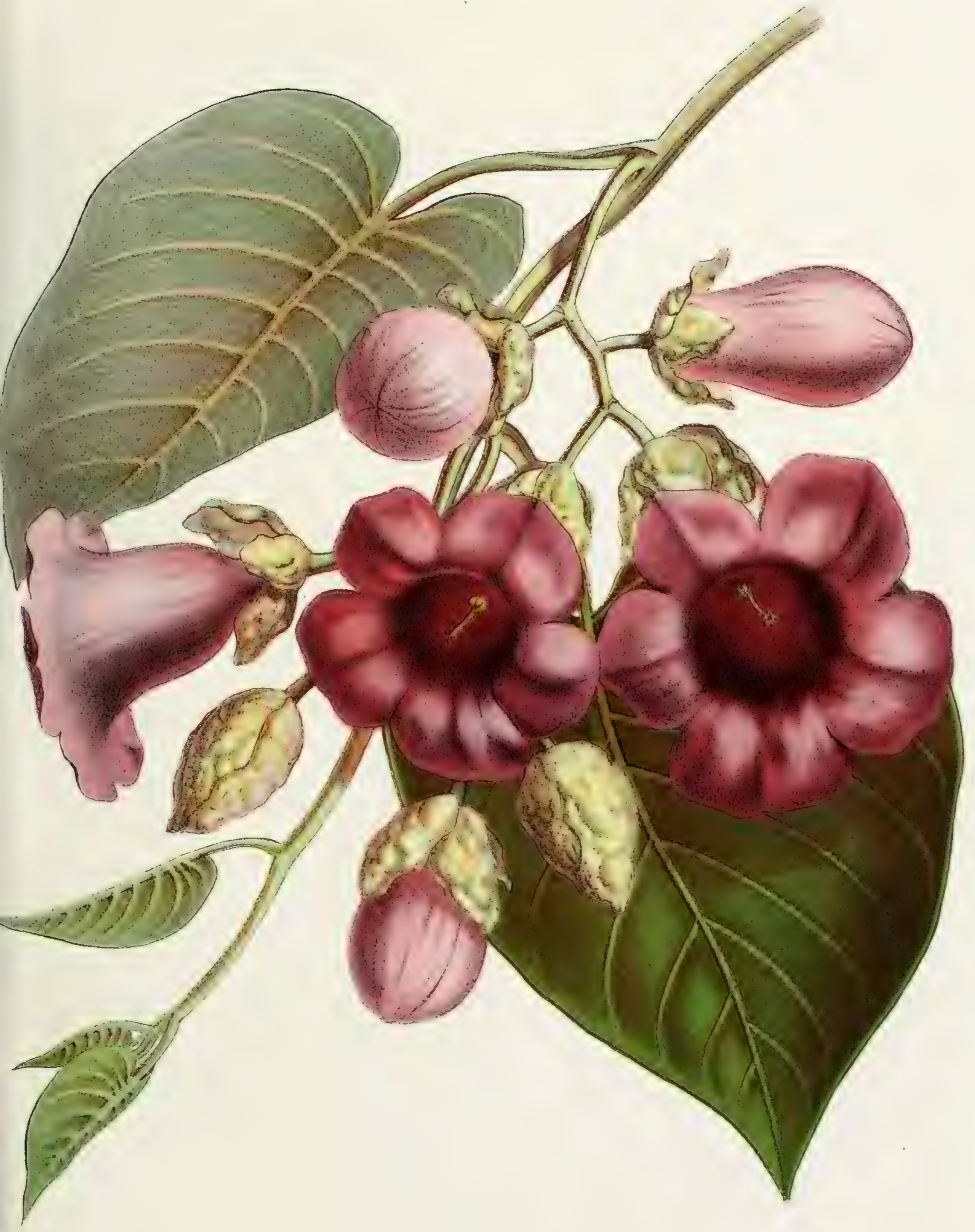

ARGYREIA NERVOSA 




\title{
EUPHORBIA BOJERI.
}

\author{
NATURAL ORDER, EUPHORBIACEE.
}

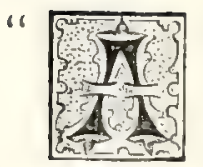

SMALL, succulent, thorny stem and Cactus-like plant, always in blossom, but particularly in the hot season, with its flat quadrangular, very symmetrical trusses of most brilliant vermilion flowers." Thus writes Ferminger in his usual concise and pointed manner.

This plant is frequently used as an edge or bordering; it is then kept close to the ground, and when in full blossom the dazzling scarlet flowers show to great advantage against the dark stems and shining leaves.

It is most easily propagated by cuttings and grows anywhere, though a mixture of charcoal in the soil is said to improve it. The thorns render it an impenetrable hedge and are a great feature of the plant; they grow in profusion down the stem, and are often more than an inch long.

The milky juice of the Euphorbia Order will be well known to all cultivators of flowers and lovers of horticulture, and this specimen is no exception; the sticky, disagreeable liquid flows abundantly where any part of the bush is broken, and leaves a stain on the hands or on anything on which it may drop.

I find many of the Euphorbia mentioned in Major Drury's "Useful Plants of India," as of use both medicinally and for industrial purposes. "From the milk of 'Euphorbia Cattimandor," he says, " a strong cement is made; it is also employed as an outward application for rheumatism." "Specimens of the gum from this plant," he adds, "were sent to the great Exhibition in 1851, as well as to the Madras Exhibition."

It will generally be admitted, I think, that "Euphorbia Jacquiniflora" is one of the most showy varieties, but it is not so universally known or so hardy to plant as the one in the picture. It is generally grown in pots and not in open ground; when in full blossom it is very dazzling and brilliant, "with a profusion of small, dazzling vermilion flowers, from the extremity of and all down its long, smooth, slender, twig-like stems." (Ferminger.)

In one season the branches of this variety have been known to be about seven feet long.

A sunny position is requisite to the growth of these plants, and they often damp off if exposed to too much rain and under the shade of large trees. 


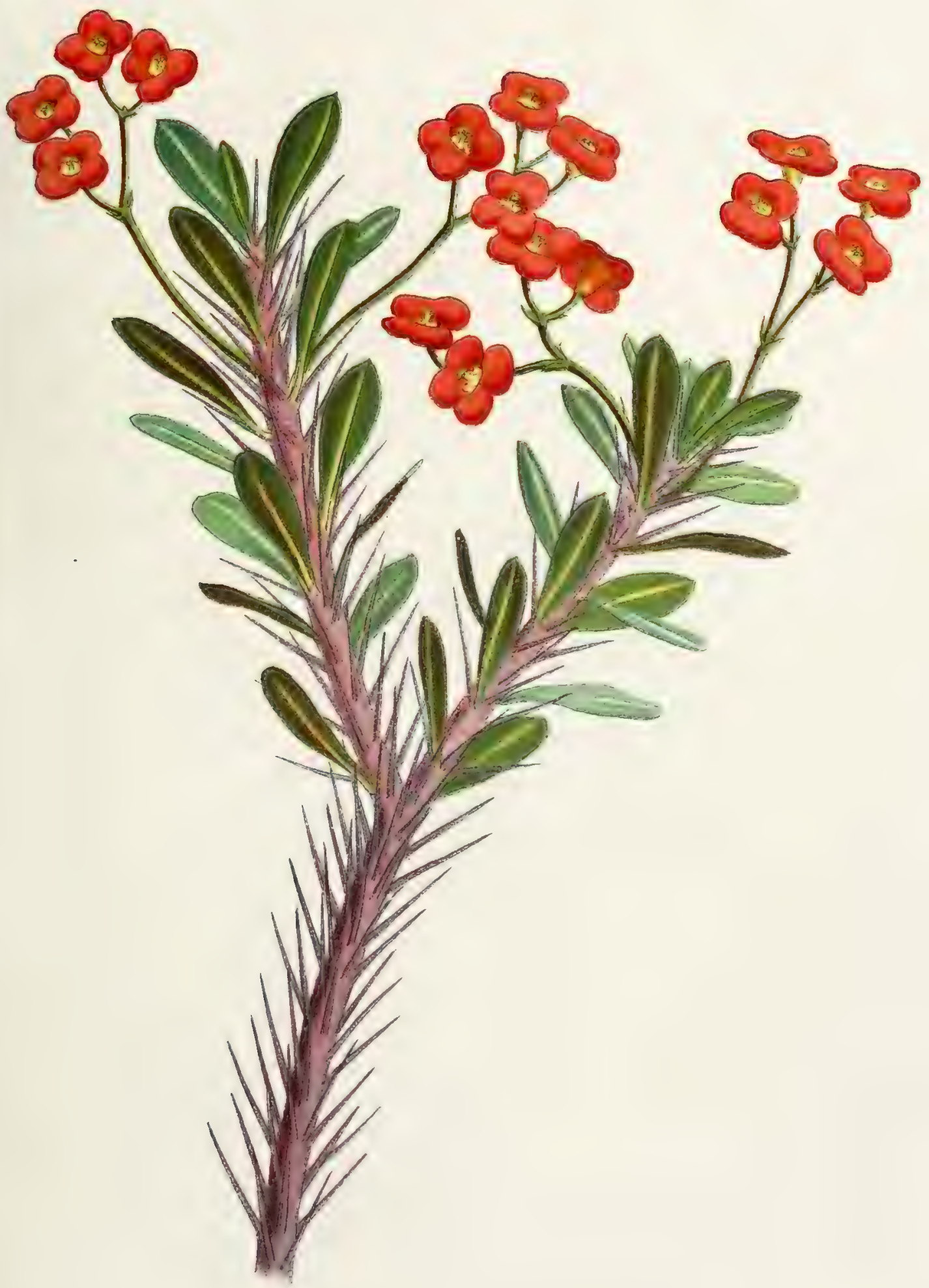






\section{BIGNONIA VENUSTA.}

NATURAL ORDER, BIGNONIACEE.

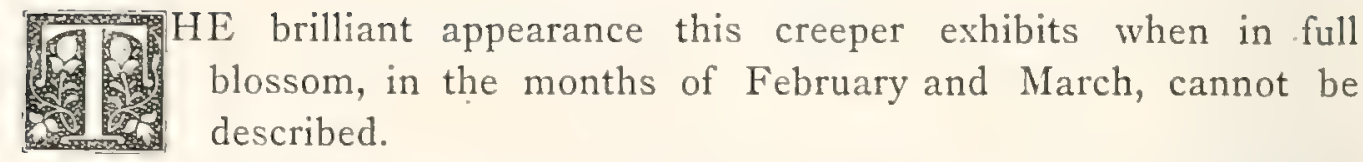

The branches of tubular orange-coloured flowers, drooping amidst the bright, shining leaves, form a lovely spectacle.

It requires a strong support, and will often climb up high trees. The lower stems have a bare and unsightly appearance, if the plant is allowed to get too straggling in its growth; it should, therefore, be severely pruned to keep it within bounds.

The tubular throat is sometimes two inches long, while the lip is curved back, exposing the green stamens.

There are some eight or ten flowers on each bunch, and when the entire plant is covered with these gorgeous heads of blossom, it presents a perfect blaze of colour, and is most ornamental.

It is a native of India, and may be seen in all parts. If allowed to trail on the ground it will send out roots at the joints of the leaves, forming young plants.

The usual mode of propagation, however, is by cuttings, which take most readily. The young tendrils are of a pale, greenish colour, very soft and pretty.

I cannot find any flower of this name in Roxburgh, but his description of "Bignonia Grandiflora" so agrees with this that I think they must be identical.

Many of the Bignoniaceæ are large and handsome trees, but these I have never seen. Roxburgh mentions one, "Bignonia Undulata," which has the same coloured flowers as our specimen; but it is a large tree, with trunk as thick as a man's thigh.

There is another pretty variety, called by Ferminger "Bignonia Incarnata." It is almost white, with a deep lilac or purple inside the throat.

The leaves of this specimen are heart-shaped, some being three or four inches long, smooth, and very numerous. 




\title{
BARLERIA CRISTATA.
}

\author{
NATURAL ORDER, ACANTHACEÆ.
}

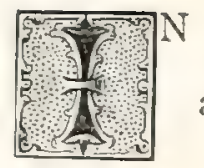

some parts of India this plant and many of the same species are found growing wild and most luxuriantly in the jungles.

It is, however, so ornamental that it deserves a place in every garden; the bush is of a compact and pleasing growth, and when in blossom forms an agreeable spectacle, but unfortunately it soon loses its pretty appearance, as the delicate flowers droop and wither very quickly, and a shower of rain spoils them at once.

During the cold weather it grows in great luxuriance in the jungles about Chota Nagpore, and Roxburgh says "it grows wild in the forests of Silhet."

The long throat-like corolla of the flower is of a paler colour than the lips.

There are some varieties of the Barlerias which bear their flowers on wheat-like heads, each flower growing out of a division of the so-called wheat. One of these I have seen growing to a great extent, the stems being erect and the flowers a deep crimson. Another has a pale orange flower; this is a smaller plant, and is often kept as a pot plant to decorate rerandahs.

The juice from the leaves of this variety "is given to children in fevers. The ashes of the burnt plant are also used medicinally." - Ainslie.

The easiest mode of propagation is by division of roots; the seed so soon drops or is blown away that it is difficult to gather it.

I never tried cuttings, but I daresay that would answer very well. 


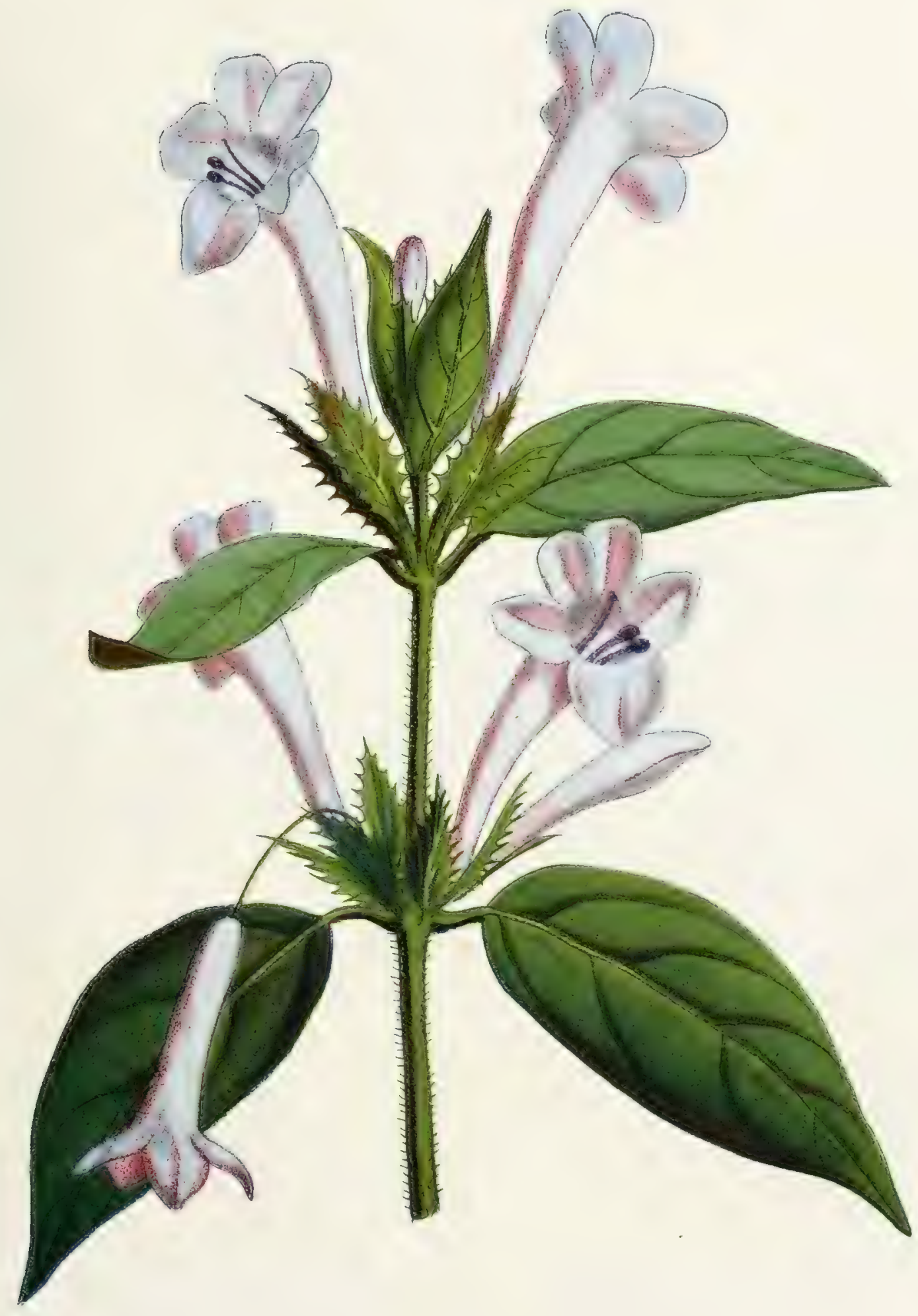






\title{
QUAMOCLIT PENNATUM.
}

\author{
NATURAL ORDER, CONVOLVULACEE.
}

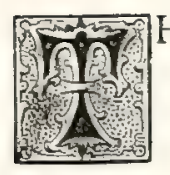

HIS climber, which becomes almost a weed when once introduced into a garden, is an annual. During the rains it is in great beauty, and its bright green, feathery foliage is spangled over by the cheerful starlike flowers.

It is of a twining, grasping nature, and woe betide any unfortunate sapling or tender bush which comes into its clutches, for it will be completely smothered in the embrace of the Quamoclit.

The slender stems are of a bright green colour and succulent nature, the leaves of the same bright green colour and very finely divided, while the flower is of a vivid scarlet or pure white; for there are two varieties.

When these two varieties are growing together, the beauty and brightness of the combination may be imagined.

"When trained up a pole," remarks Ferminger, "this plant, as seen from a distance, has somewhat the effect of a Cypress."

"Quamoclit Phœniceum" has very similar flowers to those of our picture; but the leaves are totally different, as they are thick and heavy, and of a heart shape. This species flowers during the cold weather. It is also a vigorous and aspiring climber.

Students of Roxburgh and Willis will find this plant classed as "Ipomæa Quamoclit," and the Natural Order given as "Lettsomix"; but to the general botanist, I think the name at the head of this paper will be the most familiar.

This delicate, fragile-looking plant is found almost in every part of India, and is so easily propagated by seeds scattered by the wind, that it has often to be pulled up as a weed.

I cannot find it alluded to in Drury, Ainslie, or other authorities as useful, either medicinally or economically, and so conclude it is only. ornamental to our gardens. 


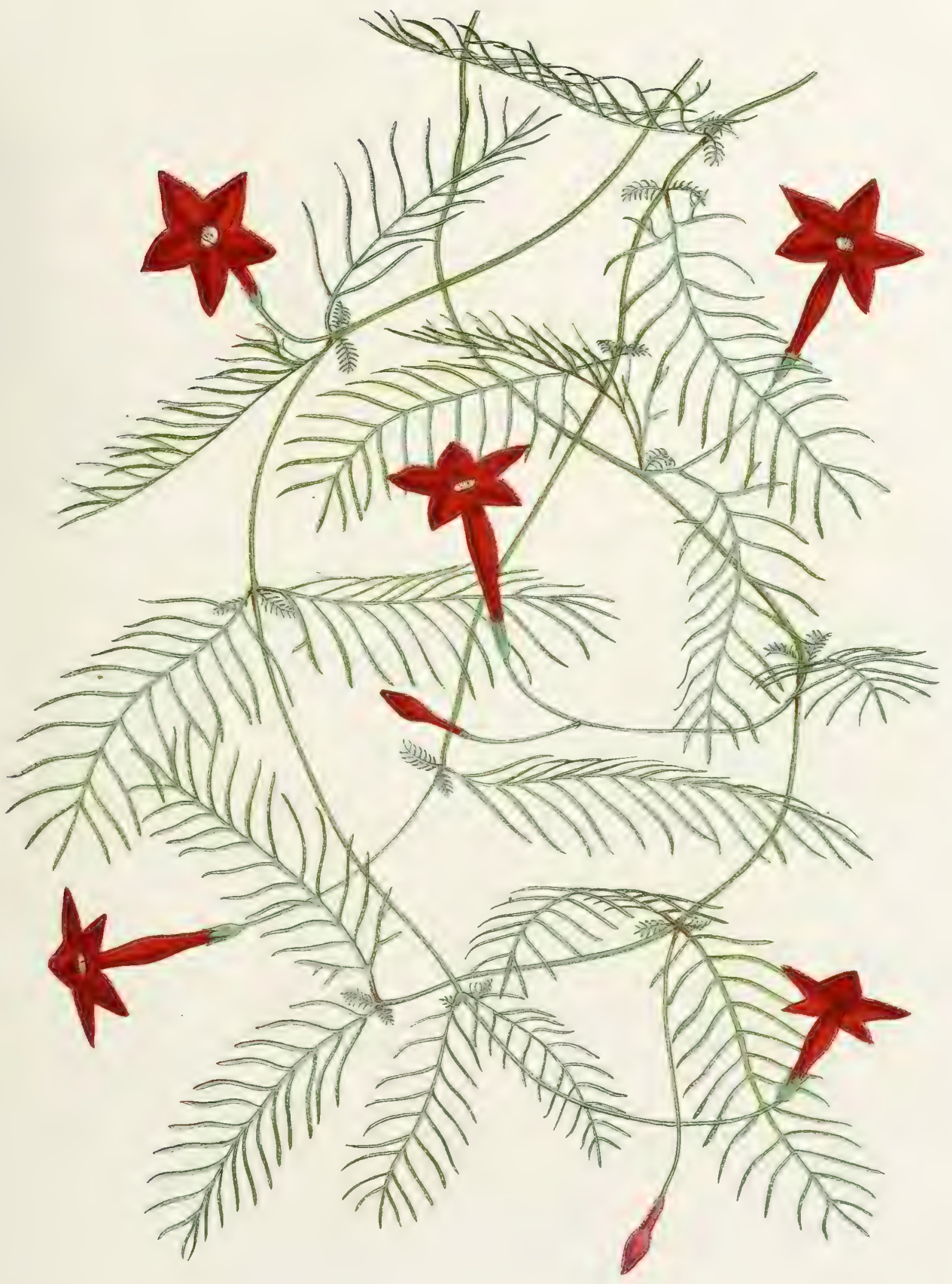






\section{OPUNTIA VULGARIS. \\ PRICKLY PEAR. INDIAN FIG.}

NATURAL ORDER, CACTACEE.

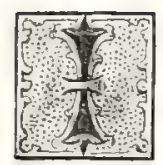

FIND that this, like most of the Cactaceæ, is a native of South America, and that Dr. Voigt states it had been introduced into Lower Bengal, but had never flowered. Possibly the climate there is too damp, for further north and in Chota Nagpore it blossoms most profusely.

It is a large, spreading, ramous bush, with thick, succulent, oval leaves, covered with numerous needle-like spines which spring from bunches of fine, penetrating hairs.

The thorns or spines are very sharp, about an inch or more in length, of a whitish colour except the tip; the small bristles or fine hairs are detached with the slightest touch, and being so fine are almost imperceptible, but give great pain and inconvenience if once they have penetrated the skin.

The flowers are of a beautiful bright yellow colour, proceeding from the edges of the thick succulent leaves. The outer petals are tipped with carmine.

I find the following interesting note concerning this flower in Ferminger: "A description of Cactus, which bears a large, pear-like fruit covered with sharp needle-like spines. On cutting open the thick, succulent rind of the fruit, a jelly-like pulp is found, which, though of little flavour, is cool and refreshing. It is sold in immense quantities in Egypt, where the poor almost live upon it."

Roxburgh, too, has given a very minute account of this plant under the name of "Cactus Indicus"; he mentions that the "Cochineal insects lately brought from America thrive and multiply upon this plant."

The natives often make use of this prickly bush as a garden fence, and a very impregnable one it is, as can well be imagined.

One leaf placed in loose mould or silver sand will soon grow and send out shoots.

The Cactaceæ are generally considered to belong almost exclusively to America, but as many varieties grow wild in the jungles in this country they must have been naturalised at a very early period. 


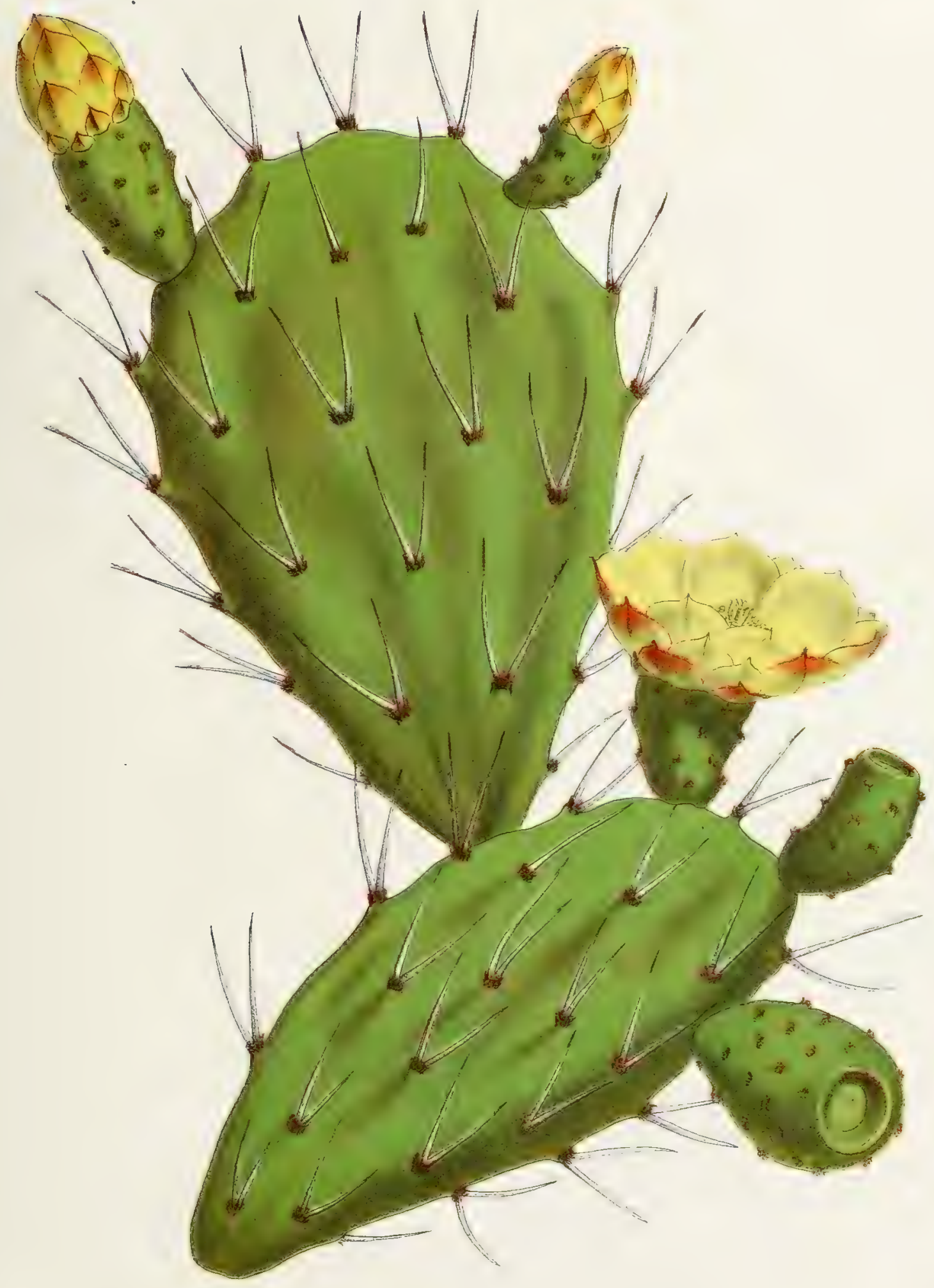

Jena Lowis del D Blars lith 




\section{BEAUMONTIA GRANDIFLORA.}

NATURAL ORDER, APOCYNACE正.

HIS is one of the most magnificent climbing shrubs to be met with in this country.

The stems are thick and woody, and the foliage very dense, the shape of the leaves somewhat resembling those of the laurel, but larger and more deeply veined.

Ferminger remarks: "It spreads over an immense space its dense foliage-curtain of noble, verdant, oval leaves, nine inches in length and four broad."

The flowers also may have the title "noble" applied to them, for they are truly magnificent. Of a beautiful pure white, and long trumpet form, sometimes about six inches long, growing out of a brownish calyx.

There are several flowers close together, but seldom more than two opening at the same time.

It blossoms in January, continuing to put forth its lovely white Howers well into March, when the heat begins to wither the flowers.

It grows most rapidly. I planted one to cover an ugly well-pole, and in a few months it had reached nearly to the summit, grasping the pole with strong tendrils more like rope than anything else.

The most pleasing way of seeing this plant is growing over a mango, or some large tree, when the beauty of its numerous trumpet-flowers and large green leaves mingle well with those of the tree.

Being an evergreen is also an additional charm, as its leaves are large, striking, and handsome, and look fresh and bright all the year.

The leaves are very large, sometimes even nine inches long and four or five broad; the veins are well defined, and the texture of the leaf is thick and leathery.

It has been quite impossible to do justice to this lovely plant in so small a space, but being so well known, and met with in every garden, I have not liked to omit it altogether.

The propagation of this plant is usually by cuttings, though it might be raised from seeds. 


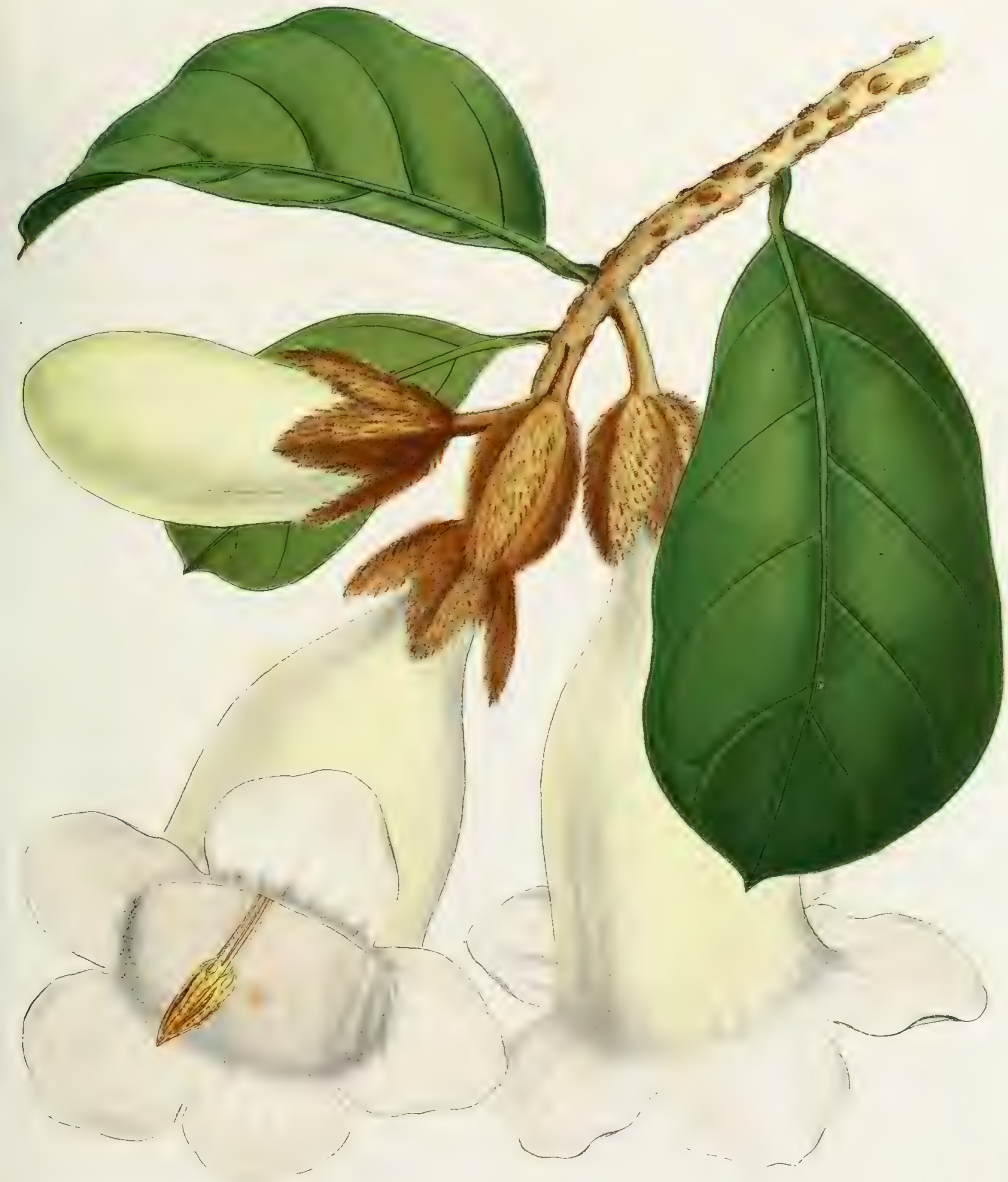

Iena Lowis del.D Blair lith 




\section{JATROPHA MULTIFIDA. \\ PHYSIC NUT. CORAL PLANT.}

NATURAL ORDER, EUPHORBIACEE.

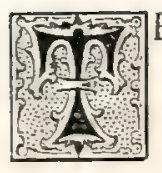

HIS plant belongs to the same genus as the Tapioca, the botanical name of that being "Jatropha Manihot."

There is much resemblance in the growth of both bushes, and in the palm-like, deeply serrated leaves, but the Tapioca plant could never claim the name of "coral" for its flowers, as they are of a pale, yellowish colour.

The style and character of the leaves is shown in the plate, but they grow so large that only a middling-sized one could be produced; they are borne at the summit of a long, rod-like stem, a large cluster at the head of each, with one bunch of these coral-like flowers shooting up from the centre.

The whole has a very graceful, pleasing appearance, especially when waving in the wind. It is necessary, however, to keep the bush pruned, or the stems get too scraggy, and give a woody, ugly look to the plant.

The foliage is both the peculiarity and the ornament of this shrub, from its long, much slit, and deeply cut lobes.

The trunk is short, dividing into the above-mentioned long, straight branches or "rods," which are of an ash-coloured bark.

The bright red coral flowers are insignificant in themselves, though when numerous bunches are out at once they give a pretty, spangled look to the bush.

The seed is of a round, bullet shape, described by Ferminger as a "large nut." These it bears profusely, and when turning ripe and yellow they look very bright and pretty.

I cannot find this particular species mentioned anywhere as being of use medicinally, but from the roots and juice of other varieties oil and medicines are extracted. When writing of the "Jatropha Manihot," Drury remarks: "It is from the juice of this plant that the Red Indians in South America prepare the most deadly mandioc poison with which they tip their arrows; this is procured by distillation, and it is said that thirty drops will cause the death of a human being in six hours."

"The pale or whey-coloured juice," says Dr. Roxburgh, "which exudes from a fresh wound of this plant is employed by the Hindoos to remove films from the eyes."

Like all members of the Euphorbiaceæ order, this plant exudes a milky juice when broken. It is met with in almost every part of India, but Coromandel and Travancore appear to be its favourites. 







